\title{
Этиологические заметки: «История об Иване»
}

\section{Богумил Гасанов}

Članek obravnava ukrajinska obscena folkloran besedila, ki jih je objavil Fedor Vovk. Vključena je tudi njegova možna povezava s pravljico A. S. Puškina »Car Nikita in njegovih štirideset hčera«. Elementi besedila imajo slovanske folklorne vzporednice, kar vodi k sklepu o ljudskem izvoru avtorskega umetniškega besedila. Postavlja se naslednje vprašanje, ali je raziskovano besedilo lahko oddaljen odmev slovanskega etiološkega mita o tem, kako so ženske pridobivale genitalije. Čeprav imajo takšni miti poganske korenine, domnevamo, da so poganski bogovi prototipi glavnih likov v ukrajinskem besedilu. Tako besedilo, posneto kot nespodobna šala, lahko dopolni zbirko etioloških mitov in legend o tem, kako so prvotni ljudje pridobili genitalije. KLJUČNE BESEDE: Ukrajina, Baba jaga, žaba, spolovila, etiološki mit, erotična folklora
This article represents research on an obscene Ukrainian folklore text published by Fedor. Vovk. Its possible relation to the verse fairy tale, "Nikita the Tzar, and his Forty Daughters", by Aleksandr S. Pushkin is considered. The elements of the text are given Slavic folklore parallels, which enables making a conclusion about the clearly folk origin of the creative product. The following question is raised: can the text under research possibly be a distant reverberation of the Slavic etiological myth about how women acquired genitals? While such myths might have pagan roots, a suggestion is made that pagan gods were the prototypes of the main characters in the Ukrainian text. Thus, the text, recorded as an obscene joke, can supplement the collection of aetiological myths and legends about how the original people acquired genitals.

KEYWORDS: Ukraine, Baba Yaga, frog, genitals, etiological myth, erotic folklore

Обращаясь к изучению эротического фольклора, исследователь, волей-неволей, должен преодолеть морально-этические установки, полученные при воспитании. В этом помогает колоссальный опыт предшественников, издавших в области славянского фольклора такие труды, как «Das Geschliechtleben des ukrainischen bauernvolkes folkloristische erhebungen aus der russischen Ukraina» В. Гнатюка (1909), «Русский эротический фольклор» (1995), «Секс и эротика в русской традиционной культуре» (1996), «Белорусский эротический фольклор» (2006), «Фолклорен еротикон» (1993-1999), «Срамотно и погано у пиротском говору» Д. Златковича (2001), «Скришен фолклор» С. Мильова (2002), «Заветные истории южных славян» Ф.С. 
Краусса (2009), «Заветные частушки» А.Д. Волкова (1999), Erotske narodne pjesme (1984), «А диња пукла. Еротске народне песме» В.С. Караджича (1987), «Народные русские сказки не для печати» А.Н. Афанасьева (1997) и «Заветные сказки» Н.Е. Ончукова (1996), «А се грехи смертные... Любовь, эротика и сексуальная этика в доиндустриальной России» (1999), «Веселая эрата. Секс и любовь в мире русского Средневековья» Е. Мороза (2011), «Эрос и порнография в русской культуре» (1999), «Анти-мир русской культуры. Язык. Фольклор. Литература» (1996), и множество других. От самоцензуры, настоятельно требующей все нелитературные слова заменять троеточием, удерживает лишь соображение о том, что стыдливость не может быть самооправданием исследователя, что статья предназначена для научной публикации в узких кругах, и то обстоятельство, что в противном случае исследование будет невозможно в принципе, поскольку собранный для работы материал из-за обилия пропусков станет трудно воспринимать. Кроме того, нужно помнить и о том, что обсценная лексика произведения отнюдь не обязательно говорит о непристойном смысле текста.

В 1898 году в парижском издании КРҮПТ’A $\Delta \mathrm{IA}$ (vol. V) Ф. Вовк опубликовал подборку текстов украинского эротического фольклора - акт, требующий что тогда, что ныне как изрядной решимости, так и, в хорошем смысле, фанатичной преданности науке и культуре своего народа. На страницах 175-176 на украинском языке и во французском переводе приводится текст, далее нами исследуемый. Также его можно видеть (в откорректированной орфографии) в современном издании статей $Ф$. Вовка, где приведены разночтения между рукописью и публикацией (Криптадії Федора Вовка 2018: 66). Текст выглядит, с учетом разночтений, следующим образом:

«Був собі Іван Переїбан-Переплетипизда, куцої пизди онук, та було у його сім дочок, та всі без почёк. А за річкою, за Сухоёбівкою жила баба Анастасія Сорокопиздасія. Пішов до неї Іван Переїбан-Переплетипизда, куиої пизди онук, пизд куповать: «Здорова була, баба Анастасія Сорокопиздасія!» - «Здраствуй, Іване Переїбане-Переплетипиздо, куияої пизди онуче!» - «Продай мені пизд!» - каже. Пішла баба у коморку, та винисла пизд мірку: «Вибірай, Іване Переїбане-Переплетипиздо, куиої пизди онуче!» Він вибрав собі сім: руду, чорну, сиду і всяку, яка ёму наравилась, а баба єму дала и восьму на придачу. Прийшов Іван Переїбан додому, поклав дочок на піл - сокирою иъюкне $і$ пизду уткне; усім дочкам порозтикав, а вісьма осталась. «Ну, тепер, Іване Переїбане-Переплетипиздо, куцої пизди онуче, як ти мене ніде не определиш, то я у тебе на носі почіплюсь!» От Іван перерубав іï на сім кусочків и усім у пизди семеники ${ }^{1}$ поставляв». Текст нами приводится не полностью, поскольку небольшое продолжение, как кажется, выпадает из сюжетной линии, и дается в сноске 2 . О месте записи сказано: «Полт(авская) губ(ерния)

\footnotetext{
1 Во французском переводе семеник переведено как clitoris «клитор». Вариант того же слова - семен (Криптадії Федора Вовка 2018, 292; Бандурка 2001, 52). Сравни рус. жарг. Семен Семенович «клитор» (Хукка 1992, 172). В украинском фольклоре также обыгрывается созвучие слова и имени: семен-Семен (Hnatjuk, № 32). Быть может, активная Семеновна из русских частушек (в том числе, нескромного содержания) обязана своему «отчеству» как раз этому термину?

2 «Тепер Семенич Пиздисеменич і Дорош над пиздами сторож, а заяи говорить: «Дай-но я попробую,
} 
Зеньк(овский) п(овет), м(естечко) Ковалівка» (Криптадії Федора Вовка 2018: 290). Для дальнейшего удобства назовем этот текст «История об Иване».

Сюжет «Истории об Иване» отчасти перекликается со стихотворением А.С. Пушкина (1799-1837) «Царь Никита и сорок его дочерей» (март 1822): у царя сорок дочерей, не имеющих влагалища; по совету он отправляет гонца к ведьме, живущей в лесу; гонец несет ларь с «добром», полученным от ведьмы, из любопытства открывает, и все «птички» разлетаются; ведьма учит гонца, как их поймать, тот привозит искомое царю; «птичек» отдают царевнам (Пушкин 1947: 248-254). Возникает естественный вопрос: не могло ли пушкинское стихотворение в каком-нибудь списке попасть на Украину, а затем в устной передаче быть записано как этнографическое произведение? Если сравнить оба текста, то можно обнаружить, что общего у них - лишь основная линия повествования: у мужчины имеются дочери без первичных половых признаков, их дает некая «знающая». Различий же гораздо больше. В украинском тексте нет никакого гонца, советника, отец девушек не царь (такая деталь могла ли быть упущена?), другие имена персонажей, дочерей меньше, речь идет о покупке, происходит некоторый конфликт Ивана с лишней вульвой, окончившийся созданием «семеников». Более того, история имела текстуальное продолжение. В стихотворении все метафорично, а в украинском тексте максимально используется экспрессивная лексика, собственно, и придавая истории колорит. Учитывая все это, о зависимости украинского народного анекдота эротического содержания от стихотворения Пушкина говорить не приходится. Очевидно, что это разные истории, хотя и с общим сюжетом, и одну вывести из другой, даже с поправкой на порчу при пересказе, было бы крайне сложно.

Объяснение сходства текстов должно быть другим. Известно, что поэт использовал для создания своих произведений фольклорную традицию и живо интересовался народной сказкой. В стихотворении о царе Никите обнаруживаются параллели с песней из сборника Кирши Данилова (Burkhart 2000: 541). У Пушкина гонец, по совету ведьмы, ловит разлетевшиеся влагалища следующим манером: «И лишь только показал - // Птички вмиг к нему слетели». Что соответствует описанной у Кирши Данилова ситуации: «Ещо забилася пиздишша в осиново дуплишша, // Ее вилами кололи - не выколали, // Калачами манили - не выманили, // Пизде хуй показали, пизда выскочила. // А токо бы де пиздушке крылошка, // A злетела бы пиздушка на мудушки» (Русский эротический фольклор 1995: 36). А.З. Жаворонков указывает, что данное произведение Пушкина «восходит своим сюжетом к бытовым народным анекдотам», и далее: «Хотя параллели между пушкинской сказкой-анекдотом и какой-либо народной сказкой установить не удалось, сказка

яке воно на вкус», - то поки попробував, то й очі повилизали». Можно лишь отметить, что слово «теперь» как бы подводит итог всей предыдущей истории, и последующая за ним часть фразы может быть понята, как несколько антропоморфизированное описание «устроения» вульвы. Пассаж про зайца, возможно, является не случайным элементом, но продолжением эротической темы текста. Подробнее об эротической и фаллической символике зайца см.: Гура 1997: 180-184. Благодарю О.В. Белову (Институт славяноведения РАН) за данное и другие замечания. 
Пушкина от начала до конца проникнута народно-поэтической стихией» (Жаворонков 1956: 101, 113). Однако, вот она - та самая параллель, в редком фольклорном тексте, опубликованном Ф. Вовком. Это мнение было выдвинуто еще в 1991 году исследователями Г.А. Левинтоном и Н.Г. Охотиным (Левинтон et al. 1991: 30). К их мнению присоединяемся и мы. «История об Иване» записана среди украинцев, в Полтавской губернии; стихотворение было написано Пушкиным в Бессарабии, где украинцы составляли изрядный процент населения. Измениться стихотворение в народном его пересказе так сильно не могло, но в поэтической переработке народный текст как раз таким мог бы получиться. Вероятно, молодой поэт, активно ищущий интересный материал и не гнушающийся эротической тематики, слышал какой-то вариант скабрезной истории об отце девушек, не имеющих влагалища (в этом варианте в принципе мог быть и гонец от царя, и оригинальный способ поимки влагалищ), и, заинтересовавшись им, использовал как фабулу для написания своей едкой сатиры на распущенного российского императора Александра I. Вероятно, из оригинала Пушкин позаимствовал и цифру 40, перенеся ее из имени женского персонажа на число дочерей царя, что было отмечено Левинтоном и Охотиным. Впрочем, не менее вероятно и то, что в этом оригинале число дочек равнялось сорока, что объясняло бы имя Анастасии, обладающей ровно стольким количеством вульв, сколько нужно. В восточнославянских сказках такое или близкое количество дочерей встречается, в частности, у Яги: «У меня есть дочери, - говорит баба-яга, бросилась в высокие терема и вывела сорок одну девицу» (Афанасьев 1957, № 105: 167), «Там моя сестра, Баба-Яга тожо живет. У ней сорок дочерей» (Русские сказки Урала 1997: 40). Русские былины приписывают близкое число дочерей Морскому Царю: «И приведет он сорок девиц да со девищею» (Новгородские былины 1978, № 36).

Суть повествования украинского текста в значительной степени остается в тени юмористической подачи истории, где упор сделан на обыгрывании экспрессивной лексики, вплетенной в имена действующих лиц. Детали проскакивают мельком, слушатель, завороженный своеобразной поэтикой, скорее всего, не успевает вникнуть в них, следя лишь за игрой нецензурными словами и общим ходом сюжета. Однако детали эти могут многое подразумевать, и потому на них стоит остановиться подробнее. Мы попробуем: 1) доказать наличие в «Истории об Иване» традиционных фольклорных формулировок и, тем самым, его бесспорное отношение не к авторскому, а к устному народному творчеству; 2) реконструировать прообраз стоящего за «Историей» сюжета, относящегося к кругу редких текстов мифологического содержания, связанных с появлением у первых людей (женщин) половых органов.

1.1. Причудливые имена-фамилии в славянской сказочной прозе-частая деталь, фигурирующая в отдельном сюжете (АТ 1562 G). Имеются среди них вполне безобидные на слух: Какофий, В-чем-я (Афанасьев 1997: 225, 265). Но есть как мужские, так и женские соромные имена, близкие к тем, что звучат в «Истории об Иване»: Насеру, Насрал, Пизда, После-доебешь, Возле-жопь-пизда, На-пизде-блоха, Епиздимия, Сиклития (Афанасьев 1997: 214, 216, 217, 218, 455, 457), Усралко, Обсеруся (Ончуков, № 72), Зае...увсех, Е...тьсяохота, Кункачешется (Подюков-Хоробрых 
2001: 11), Dyrży chuja w rukach, Pyzda miż nohamy (Hnatjuk 1909, 360), в южнославянских вариантах это имена Kurac (Хуй) и Pička (Пизда), Нuјо (Хуйо), Ebě̌ (Ебешь) и т.д. (Краусс 2009: 274-276). Не избежали этой тенденции обсценные частушки и детские считалки, где встречаются фамилии Подъебышкин, Пиздин, Залупьикин, Секелин (Трыкова 2003: 97; Ты не жми меня к березе 1993, № 296; Русский эротический фольклор 1995: 446). Так что оба главных действующих лица «Истории об Иване» с их непристойно звучащими прозвищами оказываются не изолированными фигурами. Более того, причудливому гидрониму Сухоёбівка из «Истории» также находится фольклорное соответствие: «пустился он в путь-дороженьку по речке Еблюшке» (Афанасьев 1997: 458). Последовательность имен главного героя Іван Переїбан построено на рифме, типичной для дразнилок: «Иван-болван» (Мутина 2005: 188), «Иван - болдан» (Лойтер 2001: 231), блр. «Іван - барабан» (Дзіцячы фальклор 2006: 215), это же касается и рифмы в имени Анастасія Сорокопиздасія. Прозвище Ивана звучит вполне созвучно традиционным украинским прозвищам, часто становившимся фамилиями: Сушириба, Завалипіч, Неижсало, Засядьвовк. Однако, именование Ивана включает еще один элемент, как кажется, тем самым пародируя двойные польские фамилии «панов». Переїбан-Переплетипизда звучит не менее «благородно», чем Корбут-Вишневецкий, Бонч-Осмоловский или Бой-Желеньский. Судя по украинским и белорусским легендам о происхождении «панов», их гордость - фамилии - служили частым объектом насмешки со стороны народа 3 .

И все же, дело не обязательно только в желании рассказчика ввести в фольклорную историю как можно больше выдуманных соленых названий и имен на потеху слушателя. В народе действительно бытовало обыкновение давать что людям, что населенным пунктам, что элементам ландшафта непристойные названия. И такое положение вещей серьезно беспокоило власти. Так, комментарий, касающийся списка селений Вологодского уезда за 1678 г., сообщает, что он не полон: «Несколько селений не включено из-за нецензурных названий» (Володарский 1970: 302). Законом от 31 октября 1767 г. «О переименовании земель, пустошей, речек, ручьев и других урочищ, оказавшихся при межевании с неблагопристойными названиями» предписывается: «оказавшиеся при межевании пустоши, речки, ручьи и другие урочища под названиями непристойными, а особливо срамными, в межевых книгах и планах писать иными званиями, исключая из прежних названий, или прибавляя вновь некоторые литеры по пристойности, чтобы через то имели они уже не срамные названия» (Полное Собрание Законов Российской Империи 1830: 376). В статье В.Д. Назарова приведено 67 подобных неблагопристойных топонимов, извлеченных исследователем из официальной документации XV - XVI вв. Большое число современных фиксаций подобных названий содержится в работе Е.Л. Березович (Березович 2010: 151-152). Приведем только названия нескольких

\footnotetext{
3 «Як Бог творив світ, то зробив з глини мужска. Але мужик щуо без пана? Не варт нічого. Взял Він i зробив ляха, з пиеничної муки. І поставив їх під пліт сушити. Прибіг пес, на мужиків вимочився, а пана ззів. Але Бог прийшов, дивится: нема пана! Побіг в корчі, а там пес доїдає. Він (Бог) пса вхопив за ноги, давай ним махати! I де тілько вилитіло з пса, чи на пень, чи на землю, чи на яку звірину, то з того повстал лях: (Пєньковскі, Зємянскі, Коньскій)» (Левченко, № 369).
} 
речек, которые обнаруживают определенное сходство с гидронимом из «Истории об Иване»: Еботенка, Наебуха, Ненаебуха (Назаров 1999: 557). С непристойными именами все обстояло аналогично, хотя примеров тому немного. В изданных С.Б. Веселовским «Актах писцового дела» отмечено три носителя фамилии ПиздякинИван Никитин, Иван Иванов, Афанасий Иванов (Веселовский 1977: 255). Притом, что в его же «Ономастиконе» этой фамилии нет. Остается только догадываться, сколько подобных имен и фамилий не попало в печатные источники по причинам этического характера. Пропускали только более-менее безобидное, наподобие неблагозвучных: Бздячий, Пердло, Пердун (Тупиков 1903: 48, 300), Пердунов (Кюршунова 2010: 417). Вряд ли ситуация с антропонимикой и топонимикой на Украине сильно отличалась.

1.2. Относительно Ивана в «Истории» сделано любопытное уточнение, он - «куцої пизди онук». Эта деталь могла возникнуть с учетом знакомства аудитории с неким фольклорным персонажем с именем, которое можно восстановить как Куца Пизда. В украинской игровой традиции имела широкое распространение игра в жмурки под названием «Куца-баба», «Куці-баба», известная у чехов как slepá baba, hra na slepou babu, kuca baba, и поляков как ślepa babka, ciuciu babka (Потебня 1865: 92). Украинское куций - «короткий, низкого роста», следовательно, речь идет о женщине (старухе), небольшого роста. А. А. Потебня, указывая на слепоту Яги и незрячесть водящего в игре, изображающего «слепую / короткую бабу», прямо отождествлял две эти фигуры (Потебня 1865: 94). Это соображение можно подкрепить рядом ссылок. В польской сказке о трех ягах (jędzach), имя одной близко тому, что звучит в игре: Куца (поль. Киса) (Kolberg 1881: 13). На избу Яги могут указывать слова, которыми начинал игру в «жмурки» водящий (Липецкая обл., Добровский р-н): «Кулю, кулю, бабка, // Куриная лапка...» (Иващенко 2018, 61). В характерной манере «Истории об Иване» куцую бабу могли переделать в более экспрессивную форму, где коротка не она сама, а ее гениталии. Скорее всего, данная подробность не имела непосредственного отношения к исходному сюжету (о котором далее), но в качестве фольклорного признака ее следует отметить.

1.3. Баба Анастасия обитает за речкой, что в истории подчеркнуто необычным именем водной преграды. Это рядовая для волшебных сказок деталь: река (иногда огненная, кровавая) служит границей, отделяющей мир живых от иного мира - мира богов или умерших, мир профанный от мира сакрального. Герою сказки или мифа нужно суметь ее преодолеть, чтобы достигнуть жилища кого-либо из обитателей потустороннего пространства и получить от него чудесные дары. Так, достаточно типичным является размещение за рекой сказочной ведьмы - Яги, доброй помощницы героя или его лютого врага: «За тридевять земель, в тридесятом изарстве, за огненной рекой живет Баба-Яга» (Афанасьев, № 159: 379); Кощей похваляется своим конем: «за степной рекой, у Бабь-Яги пас кобылии мой конь» (Народная поэзия Арзамасского края 2002: 212). Хождение Ивана к явной «знающей» за вульвами для дочерей вполне укладывается в этот сюжетный ход.

1.4. Вульвы баба Анастасия выносит в некоей мерке. Словарь дает следующее определение украинскому слову мірка: «Народно-бытовая единица объема сыпучих 
тел вместимостью от 16 до 26 кг и посуда такой вместимости. Зерно для продажу та інші сипкі речовини міряли пудами, а в хатньому господарстві-міркою // Деревянная посуда в виде выдолбленной колоды разных размеров для хранения зерна, муки и т. д.» (Словник української мови 1973: 746). О такой посудине и идет речь в Истории. В пудовую или большего объема мерку могло войти значительное число объектов, хранимых Анастасией. Для сюжета может оказаться важным потенциальная связь «мірки» с идеей плодородия, урожайности, обилия и, в конечном итоге, жизни. В используемых в народе емкостях хранится зерно, известный символ жизни и плодовитости. В емкости, принесенной бабой Анастасией находятся женские половые органы, то, откуда выходит новая жизнь. Если идти еще дальше, то нужно отметить, что в фольклоре практически любой предмет, имеющий полость, включая посуду и иные емкости, мог использоваться для метафорического обозначения женских органов. И тогда сама мерка для зерна, принесенная Анастасией, тоже образ влагалища. Сравни в этой связи начало русской эротической пословицы: «Не на то пизда сшита, чтобы сыпать в нее жито» (Афанасьев 1997: 496).

История ничего не говорит о том, как Иван нес вульвы домой. Если Анастасия выносит множество органов в мерке, то Ивану нужно лишь семь, но и для переноски такого количества понадобилось бы какое-то вместилище, нечто вроде ларца, «полный грешными вещами», который использует гонец царя Никиты из произведения А.С. Пушкина. Вероятно, данная деталь выпала из Истории как несущественная для сюжета. Однако имеется фольклорная параллель, как мерке Анастасии, так и гипотетическому вместилищу, использованному Иваном. В белорусской свадебной песне говорится, что старший сват «найшоў сумку з піздами /.../ А іх жа там трыцицаць шэсиь» (Белорусский эротический фольклор 2006: 174), Далее песня уточняет, что «аны каждая разнашэрст», что по смыслу вполне соответствует описанию содержимого мерки бабы Анастасии. Из принесенного «товара» Иван выбирает: «руду, чорну, сиду і всяку».

1.5. Половые органы для дочерей Иван получает в ходе покупки. Это также не проходная деталь, возникшая у конкретного исполнителя «Истории об Иване», но вполне традиционный мотив. Тема купли-продажи гениталий регулярно обыгрывается в восточнославянском эротическом фольклоре. Женщина находит деньги, чтобы «купить» фаллос для мужа (Афанасьев 1997: 54); идет с торга, неся торбу этого же добра (Бандурка 2001: 58); мать советует дочери продать шубку, чтобы купить фаллос (Русский эротический фольклор 1995: 508); мужик продает на базаре «чудесный урожай» (Афанасьев 1997: 73; Криптадії Федора Вовка 2018, 60-62; Hnatjuk 1909: 340-342); на базар везут мелкий товар - мужские гениталии, по дороге телега с ними разваливается (Русский эротический фольклор 1995: 88); парень сломал фаллос и идет в город покупать новый (Русский эротический фольклор 1995: 519); старик со старухой сдают свое «добро» в ломбард, чтобы улучшить материальное положение (Подюков-Хоробрых 2001: 16).

Часто это теоретическая возможность (в том числе связанная с оппозицией «продать / отдать даром»): блр. «Як пайду я па сенях // Да па новенькіх, // Як найду я трох курачак // Да усё чорненькіх. // Каб нашоўся купец, // Я б і курак прадала, 
// Каб харошы маладзеи, // Я б і так аддала» (Белорусский эротический фольклор 2006, 163), укр. «Куповали поцьку купці - // Не продала» (Криптадії Федора Вовка 2018: 85; вар.: Україньскі сороміцькі пісні 2003: 86, 87), «Наӥхали купці з Холма // А питали: по чому вовна?» (Бандурка 2001: 14; вар.: Бандурка 2001, 76). Но бывает, и возможность реализованная, причем в форме, достаточно близкой той, о которой идет речь в «Истории об Иване»: укр. «Нема свата дома, // Поїхав до торгу // Чарок купувате, // Перезву частвате; // Та накупив чарушечок, // Малесеньких мандушечок» (Україньскі сороміцькі пісні 2003: 126), блр. «Наш тыргавец, наш тыргавеи // Накупляв пизд, як авец, як авеиฺ» (Белорусский эротический фольклор 2006: 184). Здесь говорится об аналогичной оптовой закупке. В песне из сборника Кирши Данилова эти купцы - поп и иноземцы: «A nоп на базаре пизду продает, // Пришедши дьякон, он барышничает», «Под секелях бухариы с товарами стоят. // - А каки у них товары?? // - Эдаки товары, да голья пизды!» (Русский эротический фольклор 1995: 34, 35). Тема купли-продажи не случайна потому и в брачной тематике («У вас товар, а у нас купеи», «На товар нележальй купец неженатый»). Впрочем, множество вульв можно и просто наловить, как в широко известной русской частушке: «Как на Киевском вокзале // Тридияать три пиздь поймали, // Положили на весы - // Во все стороны усы» (Озорные частушки 1995: 52).

Сюда же примыкает идея, что половые органы будто бы можно переделать, которой в соромных сказках пользуются разные хитрецы: один обещает позолотить вульвы для успешного выхода замуж, другой - приставить женщинам тестикулы, чтобы сделать их мужчинами (Hnatjuk 1909: 344, 353). Иван приобретенные вульвы уносит, как отдельные предметы, что можно сравнить с известным эротическим граффити на каменном блоке крепостной стены Преслава. В центральной части граффити изображен мужчина с эрегированным фаллосом и разведенными в стороны руками, на фаллосе находится вульва, а вторую вульву мужчина несет в правой руке (Овчаров 1993: 65). Надо отметить, что граффити имеет больше сходства со стихотворением Пушкина «Царь Никита», где описана ситуация поимки царским гонцом разлетевшихся птиц-влагалищ при помощи своего фаллоса.

1.6. Числительные в «Истории об Иване» встречаются трижды: 40, 7, 8. Числа сорок и семь традиционным фольклором используются довольно часто.

С идеей четырех десятков фольклор и лексика связывают идею полноты (Журавлев 2016: 329), это, по сути, синоним слова «множество». Словосочетания и слова сорокоприточник, сороконожка, сорокобабник, сорок сороков не означают именно 40 чего-либо; загадка о зубах «Сорок соколов в одном гнезде живут» (Живой родник 1985: 31) говорит не о реальном числе зубов; в масленичной присказке, известной также сказке: «Уж ты ль, моя масленица, красная краса, русая коса, тридиати братов сестра, сорока бабушек внучка, трех-материна дочка» (Сахаров 1849: 329), «Русая Руса, черная коса, тридчати братов сестра, сорока бабушек внучка, трех матерей дочка» (Русские волшебные сказки Сибири 1981: 62), количество бабушек - яркая фольклорная гипербола. Встречаются и такие тексты, где число 40 связано с женским началом: рус. «Сорок аршин // П(изд)b $(u) x$ морщзин» (Русский эротический фольклор 1995: 340), блр. «У Сярожкі гарманіста // Надта доўганькі 
хуёк, // Сорак курачак садзіџฺи // I апошні сакалок» (Белорусский эротический фольклор 2006: 290). На языке фольклора сорок вульв в имени Анастасии - это эпическое число, указывающее на то, что у нее их имеется много, некий большой запас. Может сложиться впечатление, что часть из своих сорока вульв, как сообщает повествование, она готова продать. Нереальность процесса придает «Истории об Иване» дополнительный элемент комизма.

Семерка дочерей Ивана соответствует типичному в сказках, песнях и легендах количеству девушек, нередко именно сестер: «прилетают семь уток, стукнулись о землю и стали красныли девицами и стали в озере купаться» (Смирнов 2003: 260), «В некотором ичарстве, в некотором государстве у нашей сестры есть семь дочерей, семь сестер, так к ним идти - огненную реку переходить надо, она вас сожжет» (Русские сказки и песни в Сибири 2000: 88), «У Ивля Ивлевича было семь дочерей, // Осьмая падчерица» (Киреевский 1918: 73), укр. «в тому озери купаются сім дочок чарноксенжныка» (Чубинский 1878: 195). Девушки эти зачастую оказываются дочерями персонажа, обладающего высоким по меркам сказки статусом. Весьма примечательно, что такое же числительное наличествует и в легендах, объясняющих появление на небе групп из семи звезд (или семи + 1) - скопления Плеяд и Ковша Большой Медведицы (вместе с Полярной звездой): «В Хорватии около Вараждинске-Топлице считают созвездие Влашичи (Плеяды) Вилами, и рассказывают, что они некогда, еще до того, как начался свет, ходили как Вилы по земле, распевая песни и водя хороводы, как обычные хорватские девушки, семеро числом и по имени «Вилы ладарицы» (Vile ladarice), от Юрия до Ивана. Когда изменился свет (по вине христианской веры), Вилы оставили нашу землю и разместились на звездах. Так и играют до сих пор каждую ночь в свои хороводы при прозрачном воздухе, а иногда люди их из-за облаков не видят» (Kukuljević 1851: 88); «Семизвездочка по небу бегает, семь звездочек в куче, а подале Сирота, одна звездочка. Она всегда стоит, не переходит. Я от стариков сльшила: их было восемь сестер, семь-то трудящие, а эта чупырилась (капризничала). «Я, - говорит, - самая яркая»; ничто не робила. Сестры ее прогонили от себя: «Чупыришься - дак и стой тут одна!»» (Рут 2010: 160). Выдаваемые девушкам в «Истории об Иване» семь вульв находят соответствие в эротических свадебных песнях: жена тысяцкого «Рукавиць шьет из семи пиздии, // Седьма-то пизда да на иголочке» (Русский эротический фольклор 1995: 154-155). Причем первую фразу следует понимать как то, что жена тысяцкого формирует женские гениталии молодой (Мороз 2011: 32), т.е. в некотором смысле может быть уподоблена бабе Анастасии. Семь дочерей - некая устоявшаяся мифо-поэтическая норма, но, быть может, инициированная как раз образами звездного неба. Можно также предположить, что за распространенным в славянском мире представлением Плеяд группой женщин ${ }^{4}$ некогда стоял миф о первых сотворенных женщинах. Не на это ли указывает и вариант названия, которое

4 Варианты: pус. арх. Бабы; блр. витеб. Бабы; укр. Баби / Бабы, в «Лексиконе» Е. Славинецкого и А. Корецкого-Сатановского (1650 г.): Бабы звезды Pleiades; поль. Babeczki, кашуб. Babë, Bábï, Båbki, варм., мазов., мазур., подляс., помор., свентокш. Babki / Bapki, любель., подляс. Baby, малоп. Bapske gvozdy; чеш. Báby; в-луж. Baby, Babky, н.-луж. Babki. Сюда же поль. помор. Panny «девы». 
можно трактовать как «дочери Велеса» (Рут 2003: 532): рус. Волосыни (Срезневский I: 294-295), укр. Волосини (Рут 1987: 33)? Дочерями можно именовать не только рожденных, но и созданных.

Восьмерка в данном конкретном случае - лишь символ избыточности. И, что интересно, восьмерка, и в ряде случаев следующая за ней девятка, встречаются в отдельных фольклорных текстах именно в связи с женским началом: блр. «У майго мілёначка // Да акуратненькій насок. // Восемь курачак садзіциа, // A дзевяты -neтушок» (Белорусский эротический фольклор 2006: 279). В белорусских эротических песнях, исполняемых на свадьбе, рисуются следующие картины: «Мядзведзь-муравейнічак // А ўзлез на істопачку, // Скінуў карабачку. // А ў той каробачцы сем кур на вяровачиьь, // Восьмая самаволь ходзіиьь, // Пятуха за хахол водзіиь», «Гдзе ваша гаспадыня, // Што капусту варыла? // Ваша капуста пуста, // Сем пізд варылэся. // Сем пізд варылэся, // Восьмая ўвалілася. // Дзевятая самоволь ходзіт, // Пана хуя за сабой водзіт», «Над равлою, пыд пиздою // Сем пизд на мычячку, // А восьмая у карыцечку, // Яна хуя за хахол водзиць» (Белорусский эротический фольклор 2006: 161, 174, 195). Восьмая, как можно видеть, ведет себя достаточно своевольно - подобно тому, как это описано в «Истории об Иване». Параллель к цифре 8, указывающую на ее негативные «качества», находим в украинской этиологической легенде об Адаме и Еве, поясняющей происхождение женщин, не имеющих пары: «Жили вони собі, праџювали на хліб і мали сім синів і вісім доньок. Отже, то не гріх, коли брат із сестров жиє, бо коли на початку світа не був гріх, то й тепер не є. А єдна донька не мала пари і була меже братьми і мала діти. То від неї виходят оті світові дівчата, щза пари не мають» (Легенди та перекази 1985: 47). Восьмая девушка оказывается лишней, сверх нормы, и это превращается в бедствие для нее и ее потомства.

1.7. Угроза лишней вульвы оказаться на носу у главного персонажа истории находит параллель в текстах народной традиции, где сочетается телесный верх и низ. В русской экспрессивной лексике выражение вешать пизду на нос отмечено в двух значениях: 1. «проявлять желание вступить в сексуальные отношения»: «Ну какие же, девчата, // У нас парни - дураки: // Им пизду хоть на нос вешай - // Отмлахнутся, вахлаки»; 2. «Дисфм. вместо: вешать лапшу на уши» (Плуцер-Сарно 2: C. 99).

Разновидностью оборота с носом является образ вульвы на лбу. Так, в украинской песне имеется пародийное описание самоповышения статуса путем помещения на лоб знака, в данном случае напоминающего кокарду: укр. «Прийшов Роман // Забрав п... в гаман. // Повісив на лобі // Тай каже: я пан» (Криптадії Федора Вовка 2018: 257). В подблюдных гаданиях песня с подобным образом сулит девичество: «Ходит старушка по середи, // Носит пиздушку (мандушку) на черепе» (Русский эротический фольклор 1995: 233). Сравни также обещание сшить из вульвы головной убор, что сулит носящему его небывалое духовное благо: блр. «А йграй, музыка, у свой смык, // Я пашыю табе с пизды шлык. // Ни наси ж ты яго у будзинь дзень, // А наси ж ты яго у скрысення, // Будзиць тваёй душы спасення» (Белорусский эротический фольклор 2006: 180), и планы парня пошить себе головной убор: «Ямилашку не еб, 
// Пизду на шапочку берег», "Я свою-то ли милашечку // Стерег-таки, стерег, // Ее черную, мохнатую // На шапочку берег» (Русский эротический фольклор 1995: $96,514)$. В украинской этиологической легенде из Подолья описывается ситуация в начале творения мира, когда Бог планировал поместить гениталии на лбу у первых людей: «Бо то як Бог сотворив людий - з первого начала - $i$ хотів грішне тіло посадити на чолі. Али посля обдумався. Що буде зле, бо наверха» (Левченко 1928: 2). В близкой болгарской этиологической легенде Бог вместе с животными размышляет, где разместить вульву: «Если ее поместить на лоб, каждый ее достанет» (Фолклорен еротикон 1993: 135). Таким образом, единственно правильным признается нынешнее положение дел, и размещение гениталий в пределах лица оказывается нарушением божественных установлений. В боснийском варианте легенды сами женщины мастерят себе гениталии в виде яблока и ищут надлежащее для них место: «Затем одна из них предложила: «Давайте прикрепим ее ко лбу!» - «Да ты что! - строго сказала вторая. - Это некрасиво, и на этом месте она всегда будет подвержена ударам» (Краусс 2009: 342). Согласно указателю Березкина-Дувакина, этот сюжет (F17. Гениталии не на месте) широко распространен и известен на четырех континентах. У сербов (Левач и Темнич) в качестве обережной формулы невозможного используется соответствующий образ гениталий не на месте: «Если некто на что-то удивится, то для того, чтобы не сглазил, нужно ему сказать: /.../ «П... ти на челу!» (Вульву тебе на лоб!)» (Мијатовић 1909: 419). В болгарском заговоре от сглаза (Пловдивская обл.) та же формула применена к хищнику, выступающему в данном случае, видимо, как существо демоническое: «Върчица (волчица?) бяга за село // с путка на чело!» (Каблешкова 2003: 46). Также, «согласно сербскому и македонскому поверьям, вульва может выскочить на лбу у мужчины, если он ухитрится пройти под радугой» (Толстой 1995: 495), т.е. произойдет нечто невероятное. В «Истории об Иване», следовательно, вульва грозит выбрать место для себя самостоятельно: у мужчины, и более того - не на месте, где гениталиям полагается находиться, но на самом виду, чем нарушит все мыслимые и немыслимые законы.

Известен подобный образ и относительно мужских гениталий: рус. Чтоб(bl) хуй на лбу вырос! (Плуцер-Сарно 1: 119). Подобная ситуация - нечто небывалое вообще и невероятно позорное: то, что должно быть скрыто природой, оказывается выставленным на самых видных и выделяющихся на лице местах - носу или лбу. Возможно, такие образы являются пародиями или снижением фольклорных формул о небесном светиле во лбу. В сказках лоб героя может оказаться украшен месяцем, солнцем или звездою. Месяц: царица рожает «сынка поколен в золоте, полокот в серебре, по косичам часты звезды, во лбу светёл месяиу (Зеленин 2002: 42). Солнце: царица рожает нескольких сыновей, «во лбу красно солнышко, на затылке светел месяиџ» (Афанасьев 1957, № 285: 380), «по косииям ияасты звездоцьки, а в затылке светлой месяи, а во лбу красное солнышко» (Соколовы 1999: 242). Звезда: так помечает своего избранника царевна - «в ту же минуту влепила ему в лоб алмазную звезду» (Афанасьев 1957: № 564, 340), «Сняла свой перстень и ударила ево в лоб. У нево и образовалась звезда во лбу-ту: просто так и сияет» 
(Зеленин 2002: 61). В случае со звездой при сниженных вариантах вполне может обыгрываться очевидная рифма. Если размещение на лице небесных светил - признак принадлежности к «светлым силам», персонажам положительным, то верно и обратное: нахождение на лице гениталий характерно для демонических существ, в облике которых наблюдается отклонение от нормы (Успенский 1994). Эту же деталь могут подчеркивать в своем образе ряженые, изображающие приход демонических потусторонних сил на землю в дозволенное им время. Сравни описание святочных ряженых в челобитной нижегородских священников, поданной в 1635 г. патриарху Иоасафу I: «на лица своя полагают личины косматыя и зверовидныя и одежду таковую ж, а созади себе утверждают хвосты, яко видимыя беси, и срамная удеса в лицех носяще и всякое бесовско козлогласующе и объявляюее срамные уды...» (Акты исторические 1841: 96). Нужно отметить, что слово уд относилось как к мужским, так и женским гениталиям: детородный женский уд (Самойлович 1780: 8), и это позволяет предполагать, что на своих масках ряженые могли размещать имитации гениталий обоих полов.

Герой «Истории» от «персонажа» противоположного пола, как и в сказках, открывается возможность быть отмеченным знаком, который будет у всех на виду. Вот только вместо почета знак сулит лишь срам, уподобление существу нечистому, демоническому. Лишняя вульва оказывается врагом, и только смекалка позволяет Ивану избавиться от грозящей напасти, обратив и эту ситуацию на пользу всем. Он, подтверждая свое говорящее имя, наглядно доказывает свою власть над женским началом, словно фаллическое божество, разбивая его воплощение вдребезги - мотив, также известный смехоэротическому фольклору в песнях: «Пришел с Moсквы, xуй забил с тоски, // Хуй втрески, пизда вдребезги» (Русский эротический фольклор 1995: 38), и в пословицах: «Либо хуй пополам, либо пизда вдребезги» (Афанасьев 1997: 494), «Либо хуй пополам, либо пизда в щеекки», «Хуй в соплях - пизда вдребезги» (Плуцер-Сарно 2: 168, 186). В случае Ивана сработало второе. Впрочем, надо иметь в виду, что за подобными выражениями скрывается описание коитуса, и потому можно думать, что Иван расправился с лишней вульвой своеобразным способом, в прямом созвучии со своим прозвищем.

Приведя фольклорные аналогии ряду элементов «Истории об Иване», можно сделать вполне обоснованный вывод о безусловно народном ее происхождении. Представляется, что разбираемое в данной работе анекдотичное произведение из «Криптадии» вполне может иметь корни в этиологическом мифе о появлении у людей половых органов. Мифе, приобретшем исключительно смехоэротическое оформление при пересказе в определенном кругу, и, возможно, утратившем часть, где содержалось повествование о создании мужских гениталий. Сходную мысль уже высказывали ранее. Комментируя пушкинского «Царя Никиту» и его фольклорные истоки, включая «Историю об Иване», Г.А. Левинтон и Н.Г. Охотин пишут: «В то же время, они обнаруживают множество взаимосвязей с другими сюжетами, в частности, с чисто этиологическими (мифологическими) текстами о создании женщин (сначала - без половых органов, потом они делаются отдельно) или женских 
половых органов, представленными многими фольклорными традициями, в том числе славянскими» (Левинтон et al. 1991: С. 32). Статья указанных авторов не содержит конкретных примеров этих этиологических текстов, в силу чего данное соображение носит общий характер. Попробуем исправить этот момент.

2.1. Итак, на мысль об этиологических корнях разбираемого текста наводит определенное сходство украинского текста с русской этиологической легендой о появлении у первых людей гениталий, записанной в Архангельской области. «Бог сотворил цеёловека. Сотворил да сам спать лег, а иёловекам наказал, итобы из избы не выходили. Сотворёно-то, видно, много было сразу. Вот спит Бог, храпит, только гром гремит. /.../ Вот Сотона подкралса, отворил двери в ьзбу да и баёт: «Охти мне, люденьки, бежите-ко на улицю-то. Коль здись баско да хорошо: птички поют, ияветоики ияветут». Ну, как подурняя-то, дак и побежали. А Сотона стал за ободверинку с топором. Какмимо ёво коей цёловек побежит, он ёво тюкнёт да тюкнёт промеж ног. Издыроватил иеёловицков и баёт: «Будьте вы бабами, делайте все назло мужикам». Встал Бог, поханькал, поханькал, да делать нечево. Прилепил он остальным людям по шишке да и говорит: «Затыкайте бабам дыры, плодите новых людей»» (Устьянские сказки 2007: 45-46). Оба текста явно не тяготеют к серьезным жанрам и призваны позабавить. В обоих случаях вульвы делает представитель противоположного пола при помощи ударов топора. В боснийской легенде женщины сами мастерят вульву, но доделывает ее мужчина при помощи топора: «Когда бабы прикрепили пизду к обговоренному месту, пришел мастер-плотник и попросил, чтобы они разрешили ему доделать ее. Он достал топорик и рассек пизду пополам» (Краусс 2009: 342). Топор задействован и в белорусском предании, объясняющем причину того, почему у мужчин гениталии разной длины: «Колісь Бог (загадаў мужыкам перапрыгнуць праз канаву) ... Мужчына, значыць, должан перапрыгнуць этую канаву. Як перапрыгне - а там тапор пастаўлены - так ён тут (между ног) і разрязая. А на той старане стаіць другі чалавек $і$ ета ўсё зашывая. Як катораму зашыя тут дробненька, значьць, нітка астанециа маленькая, пісюнок, а як каму туды-сюды шмаргнуу, значыць, другі пісюнок больш астаециа» (Традыцыйная мастацкая культура беларусаў 6/2: 604). На топор, вероятно, указывает русская частушка, сюжетно зависимая от преданий подобного типа: «Бог ребят наказал: // Им по палке привязал, // А девчонок наградил: // Меж ног дырку прорубил!» (Волков 1999: 232). Среди образцов народного заветного юмора описана ситуация, когда мать объясняет наличие у нее гениталий увидевшему их малолетнему сыну следующим образом: рус. «Это тятька невзначай топором рассек» (Афанасьев 1997: 507), укр. «Та иее, синок, твій батько колись розсердив ся на мене, хватив сокиру, замахнувсь на мене, так кінцем і цүюркнув проміж ніг» (Hnatjuk 1909: 17). Созвучное описание обнаруживается в шуточных песнях: «Ax mbl, тетушка возлюбленная! // Топором она разрубленная», «Это все это возлюбленная, // У тебя пизда рубленная, // Топорищем подвореченная» (Русский эротический фольклор 1995: 64, 127). Такое объяснение вполне может быть вызвано соответствующими этиологическими легендами. Также к дальним отголоском подобного мифа может иметь отношение связка вульва/топор в песнях, где топором пытаются достать 
(«вырубить») вульву из дупла или пня, отделить ее от пола: «Как зашла эта пизда да глубокое дубло (sic!) // Топором ее рубили, да не вырубили» (Левинтон et al. 1991: 30), «Залезла в дуплище, // В осиновище. // Калачом-то манили, // Да не выманили; // Топором-то рубили, // Да не вырубили», «Залетела кунка в пень, // Топором ее рубили, // Не вырубили» (Русский эротический фольклор 1995: 100), «В коридоре мыла пол, // Приморозила хохол. // Дайте мне топорика - // Вырубить хохолика» (Дериглазов 1993: 166).

В других сходных легендах в качестве инструмента, создающего вульвы, фигурирует коса. Ее использует либо черт, как в архангельском тексте: блр. «Гавораи, ішлі чэраз канаву мушчыны і жанчыныл. /.../ А баба йшла, чорт касу паставіу - баба й прарэзалася. /.../ Недзе чэраз канаву чорт іх гнаў $і$ дзяліў эта «удавольствіе». А баба на касу стала, і ўяе на рубашцы стала, прарэзалася, крой пашла. І ияпер ідзе» (Боганева 2008: 98). Либо Бог: рус. карел. «Когда Бог баб да девок на свет выпускал, то косу лезвием вверх поставил и приказал им над косой пройти. Тем, кто пониже, между ног больше прорезало, а тем, кто выше, - только самым кончиком косы» (Логинов 1996: 449). В аналогичном болгарском варианте Бог применяет саблю: «Как распечатывал женщин. Забил саблю рукоятью в землю, острием вверх. Они идут и разрезаются. Которая повыше, пройдет и разрежется немного, которая поменьше, как разрежется, то до середки. Поэтому у низких пизды побольше, а у высоких - поменьше» (Мильов 2002: 20-21). Типологическую параллель к подобным действиям со стороны Бога представляет латышский вариант предания о том, как Бог увел у черта его стада и изменил характерные черты скота, прежде тому принадлежавшего: «У черта водилась скотина /.../ Бог задумал прибрать к рукам чертову скотину и построил хлев. /.../ На другой день бог вогнал в порог хлева косы», затем напустил на коров кровососущих насекомых, которые и «загнали чертову скотину в божий хлев, и все коровы рассекли копыта о косы на пороге» (Латышские народные предания 1962: 72).

В двух приведенных выше белорусских этиологических легендах упоминается канава, как некая граница, которую необходимо пересечь, после чего происходит изменение половых органов: «Колісь Бог (загадаў мужыкам перапрыгнуць праз канаву)... Мужчына, значыць, должан перапрыгнуць этую канаву» (Традыцыйная мастацкая культура беларусаў 6/2: 604). «Гавораи, ішлі чэраз канаву мушчыны і жанчыныл» (Боганева 2008: 98). В «Истории об Иване» ей соответствует річка Сухоёбівка, ведь приобретает вульвы Иван лишь преодолев ее. При этом в фольклорном поле применительно к Яге воплощение потусторонней границы варьируется от мифической огненной реки до обычной канавы, используемой детьми во Владимирском крае в своих играх: «Под окнами канава была. Делали завалинку. Играли в Бабу Ягу. Прыгали через канаву, кто упадет, тот к Бабе Яге идет» (Гурякова 2011: 55).

К описанным мифам может иметь отношение русская святочная забава. «В Касимовском районе Рязанской области еще в 30-е годы молодые мужчины и парни, собравшись компаниями человек по десять, наряжались «стариками» («дедами калёными»). «Придя на посиделки, «деды» пляшут, забавляются с девчонками. Когда это надоест, «деды» хватают девиц и выволакивают их на улицу. Поднимается 
неописуемая свалка, так как изба обычно переполнена, кроме участвующих, еще наблюдающими (главным образом дети школьного возраста). Вытащив девиц на улицу, на снег, «деды» задирают им подол и натирают снегом между ног (конечно, никаких панталон шостьинские девочки не носят, а может быть, умышленно не надевают их в эти дни). Но интересней обстоит дело, когда эта процедура совершается коллективно. Тогда двое «дедов» берут девушку за ноги и поднимают кверху, держа юбку колоколом; третий насыпает в этот колокол лопатой до пол. Девушка, подвергнутая таким манипуляциям, отряхивается от снега, произнося: «Спасибо, дедушка родимый!» - и убегает обратно в избу. Натешившись здесь, «деды» отправляются на следующие посиделки - и так всю ночь» (Морозов et al. 1996: 287). Скорее всего, это вариант распространенного по всей России обычая «солить девок», приуроченного к Масленице или Чистому Четвергу, но вариант, выпадающий из общего типа, возможно под влиянием мифологического фактора. Действия «дедов калёных» вполне поддаются трактовке как изготовление девушкам вульв, в подражание мифу. Как известно, «ритуал - это воплощение мифа. Когда человек участвует в ритуале, он принимает участие в мифе» (Кэмпбелл 2018: 119), «Обряд составляет как бы инсценировку мифа, а миф выступает как объяснение или обоснование совершаемого обряда, его истолкование» (Токарев 1980: 235). Нечто, осуществленное в начале времен в рамках мифа, должно ежегодно повторяться и обновляться в рамках обряда, неслучайно приуроченного ко времени зимних святок, когда закладываются основы грядущего года. Сделанное творцом для первых женщин, силами ряженых «дедов», возрастом придающих себе статус и авторитет, делается вновь для нового поколения девушек.

Интересно отметить, что сюжет об изготовлении женских гениталий известен и за пределами славянского мира. В Аналитическом каталоге Березкина-Дувакина мифы подобного типа сведены под номером F6. «Выдолбленная вагина». 19.20.23.52.54.-.59.62.63.68 («(Первая) женщина сперва не имеет вагины. Обычно ее делает ей птица, животное, рыба и пр.»). Среди вариантов с участием представителей животного мира есть один, относящийся к Микронезии-Полинезии, весьма близкий рассматриваемым нами славянским этиологическим преданиям: Беллона (дочь Mautikitiki родилась без телесных отверстий; М. прорезал ей вульву теслом, тесло застряло, превратилось в клитор) (Березкин et al. 2019). Топор и тесло мужские инструменты для обработки древесины, могущие служить фаллическим символом. Сходство даже в деталях. Однако, говоря о типологической близости этиологических сюжетов восточных славян и жителей области Микронезии-Полинезии, следует ограничиться замечанием, что подобные схождения обусловлены метафорикой коитуса: если фаллос может быть уподоблен рубящему инструменту, то акт автоматически будет сравниваем с работой им (рубкой, затесыванием). В южнославянских этиологических мифах также описывается ситуация отдельного создания гениталий женщины позже ее сотворения. Коза наступает копытом, чтобы придать форму, лиса касается хвостом, чтобы была мягка, пчела жужжит, чтобы стала сладка, как мед, осел лягает, чтобы у нее не было дна, от хорька достался запах (Фолклорен еротикон 1993: С. 135-136); медведица дает шерсть, чтобы была 
лохмата, лиса - лукавство, чтобы была лукава, пчела - мед для сладости (Мильов 2002: 19); индюк дает кусок подбородка, чтобы сделать клитор для охраны вульвы, медведь - шерсть, чтобы вульве не было холодно (Краусс 2009: С. 342).

Собственно, та же, по сути, картина, что и в «Истории об Иване», только в максимально сокращенной форме, весьма однотипно нарисована в коротких украинских песнях, исполняемых на свадьбе (после венчания в церкви): «Були ми у Бога, // Молилися Богу // I святій Пяттиьцьь - // Рідній матіниі - // I святому Понеділку (в рукописи: «понеділкові») // Що провертів пизді дірку» (Криптадії Федора Вовка 2018, 98), «Ой спасибі Богу, іще і Хомі, // І святому понеділку, // Що провертів дірку», «Ой були ж у Бога, // Та молімся Богу // Й святому понеділку, // Щоб провертів дірку» (Бандурка 2001: 66, 81). Бог здесь - несколько сторонняя фигура, зато два других персонажа, женский и мужской, оба высокого сакрального статуса, более активны. Песня говорит о пребывании у Бога неких лиц («були ми»), но, по сути, не только у него, но и у св. Пятницы и св. Понедельника, что сравнимо с ситуацией пребывания Ивана из «Истории» у Анастасии. Св. Пятница названа в песне «родной матерью», а св. Понедельник - тем, кто проделал в вульве отверстие. Что идентично разбираемому тексту, где баба Анастасия, как источник вульв, может быть названа матерью, а Иван место под них прорубает топором. Имеется различие лишь в инструменте и методе его использования, но, поскольку за всем этим читается типичная метафора коитуса, как некоего рабочего действия при помощи разнообразных инструментов (топор - рубка, сверло - сверление 5 ) то это различие не представляется существенным 6 . Для нас будет важно другое. Во-первых, имеется группа текстов (русских, украинских, белорусских, болгарских), близких «Истории об Иване», во-вторых, при наличии таких параллелей можно, безусловно, говорить об изначально высоком сакральном статусе прообразов главных действующих лиц «Истории». Таким образом, у нас есть серьезные основания считать «Историю об Иване» отзвуком этиологического мифа.

2.2. То, что этиологический миф на каком-то этапе своего бытования принял столь гротескную форму, смущать не должно. Это прямо обусловлено темой истории - происхождения женских гениталий. Все вышеприведенные аналогии точно так же не выглядят серьезными текстами. Их едва ли не рассказывают в сугубо мужских или подростковых компаниях, относясь как к соленой и, одновременно, назидательной шутке 7 . Одновременно с этим надо иметь в виду, что в архаичных культурах очень часто серьезное подавалось через смешное: любой миф мог быть подан как комедия, а «мистерии также могут внезапно превращаться из возвышенного

\footnotetext{
5 «я человек мастеровой, у меня струмент наготове! Сейчас проверчу!» (Афанасьев 1997: № 132).

6 Имеется текст, где фигура «св. Понедельника», проделывающего отверстие в женском теле, снижена до образного обозначения парня, согрешившего с девушкой: укр. «Святий Понеділку, // Іспортив нам дівку: // Ноги раскарячив, // Вовну покудлачив, // Не пилою, не косою, // А живою ковбасою» (УСП 2003: С. 88). Инструмент из исходных вариантов этиологического типа здесь перечисляется в качестве неиспользуемого.

7 «Между прочим, эти сказки обычно рассказываются в деревне мальчикам-подросткам (которые сами их при этом, по-видимому, не рассказывают) - ознакомление с такого рода текстами призвано оказать влияние на половое развитие» (Успенский 1994).
} 
действа в смехотворное представление» (Радин 1999: 255). Смех над божественным и вера в божественное - вовсе не взаимоисключающие вещи, поскольку «parodia sacra направлена не против культурных предметов, так как сама является одним из них, но стремится разрушить надстроенные над ними значения» (Реутин 1996: 26). М.М. Бахтин писал: «Не было такого жанра, молитвы, изречения, которые не получили бы пародийного эквивалента. До нас дошли пародийные литургии пьяниц, игроков, денежная литургия, многочисленные пародийные евангельские чтения /.../, содержавшие иногда весьма непристойные рассказы» (Бахтин 1965: 437). Веселье на тему сакрального вносит в обыденную веру человека элементы более непосредственного переживания мифа, более тактильного, если можно так выразиться, ощущения сопричастности миру божеств, ощущения их реальности и близости нашему миру. Небожители предстают через эти невинные, в общем-то, шутки близкими сородичами, с которыми можно поддерживать теплые отношения. Понятие «Бог» перестает быть холодным, отстраненным и неотвратимым, как рок, а мифы - абстрактными и маловразумительными. Таковы предпосылки для превращения этиологического мифа в непристойную шутку. Впоследствии же включается еще один очевидный механизм. Старые мифы, уходя в прошлое, забываются, теряют свой смысл, и в новых реалиях прочитываются уже не как нечто священное, но как забавная история, фарс, и то, что прежде чтилось как сакральный символ, в иных культурных установках начинает выглядеть нескромно или смешно, и соответствующим образом подается.

2.3. Присмотримся к мужскому персонажу - главному действующему лицу «Истории об Иване». С одной стороны, второе имя - комично-эротическое - Ивана косвенно подразумевает могучий сексуальный потенциал его носителя. С другой стороны, принимая версию этиологического мифа, следует предполагать, что прообразом Ивана был Бог-творец древнего мифологического сюжета, способный изменять реалии мира, вносить в них новые элементы. Кто-то вроде Бога или его антипода, Сатаны, из предложенных выше мифологических аналогий. Сатана дуалистических мифов, как безоговорочно полагают многие исследователи, - наследие богомильства. Но эта точка зрения представляется излишне оптимистичной: «с богомильской традицией вообще, и с ее влиянием на славянскую письменность и фольклор в частности, следует быть очень осторожными /.../. Дело в том, что мы не можем судить с легкостью о влиянии богомильских концепций, если перед нами есть только некий намек на дуалистическую картину мира. Слишком мало нам известно и о самих богомилах, и о возможном изначальном славянском дуализме. Мы вправе указывать на богомильство только в тех случаях, когда в источниках есть очевидные следы собственно богомильской идеологии, когда же речь идет просто о дуалистической концепции мира, разговоры о богомильском влиянии не оправданы» (Каспина 2010: 201-202). На равных основаниях с богомильской версией должна приниматься и версия автохтонная. Следует за вполне христианскими фигурами, действующими в совершенно нехристианской версии создания людей и творения их гениталий, предполагать фигуры дохристианских божеств, которые, помимо мира, творили собственноручно и людей (Прометей и Афина у 
греков, Хнум при участии Тота у египтян, Энки и Нинмах в шумеро-аккадской мифологии, тот же мотив упоминается в «Младшей Эдде»).

Шуточное срамное имя из позднего текста дает намек, что в мифологической фигуре прообраза Ивана, вполне вероятно, имелась заметная причина для дальнейшего обыгрывания его личного имени. Объединяя оба высказанных положения - о сексуальном потенциале и о божественном прототипе, - следует искать возможный исток фигуры Ивана среди мужских божеств славянского языческого пантеона, связанных с понятиями плодородия и чадородия. Собственно, искать фаллическое божество. Индоевропейским народам древности и современности известны божества с ярко выраженной фаллической символикой. Таков Шива в Индии, чей священный камень-шивалингам, собственно, и является изображением фаллоса Шивы, Индра и Агни, названные в Ригведе обладателями тысячи мошонок (PB VI.46.3; VIII.19.32), Приап и Гермес в Древней Греции, которому посвящали изображения-гермы - четырехгранные колонны с изображениями лица и фаллоса божества. Славянское язычество, судя по его отголоскам, точно так же знало фаллических богов, гениталии которых фигурировали в посвященных им текстах и были отображены в иконографии. Предположительно о воздвижении подобных фаллических изображений говорится в «Слове св. Григория» (датировка в пределах XI - XIV вв.), где осуждаются всевозможные языческие суеверия восточных славян: «чтоуть срамныА оуды. (и въ шбраз створены.) ї кланАютсА имъ. и требы имъ кладоуть» (Гальковский 1913: 23). Далеким отзвуком этой традиции, вероятно, является известное в русских частушках именование идолом полового органа мужчин: «Вынул милке из порток // На шесть вершков идола, // А она мне отвечала: // - Не такого видела!», “Что, Семеновна, // Ты там увидела? //-Мильий вынул из порток // Большого идола!» (Волков 1999: 176, 562).

Следует обратить внимание на Ярилу, фигуру которого снабжали гипертрофированных размеров гениталиями: «Доселе в Костроме Всесвятское заговенье и гулянье называют «Ярилой». Прежде на этом гулянье, по указанию Г. Диева, совершали погребение Ярилы, которое состояло в том, что старик в лохмотьях нес в небольшом гробике куклу, представляющую мужчину с естественными его принадлежностями» (Снегирев 1839: 55), «После Всесвятского заговенья сходились пополудни женщины и казаки, чтобы погулять у шинка. Там они пели и плясали до вечерней поры, потом по захождении солнца выносили на улицу мужское соломенное чучело со всеми его естественными частями и клали во гроб» (Терещенко 1848: 100), «В первые десятилетия ХХ в. в Даниловском уезде Ярославской губернии был еще жив обычай в заговенье «погребать Ярилову плешь». При этом парни лепили из глины фигуру «Ярилы» в рост человека с подчеркнутыми признаками мужской силы» (Померанцева 1997: 128). Восточнославянскому Яриле типологически близок южнославянский Герман/Джерман. Женщины (старухи или девочки) из глины, земли или же ткани, теста изготавливают одноименную куклу, которую кладут в гробик, оплакивают и хоронят (закапывают на берегу водоема, перекрестке), «обязательный элемент куклы - несоразмерно большой фаллос. ««Надо, чтобы показывал, откуда появятся тучи: они придут оттуда, куда смотрит его шапка, и 
будут двигаться туда, куда смотрит его член» (Михайловградско)» (Кабакова et al. 1995: 499). Указание на мужское естество Ярилы содержится в загадках о помеле: «Выбежал Ярилко из-за печного столба, начал бабу ярить, только палка стучит» (Иванов et al. 1974: 213), «Вышел Ярилко из задней избушки, стал бабу ярить: по шерсти, по персти, поперек шерсти. Ярил да ярил, да наярил добро» (Миненок et al. 1995: 407). Весьма примечательно, что в Рязанском крае «на вопрос Н.М. Мендельсона, кто же такой Ярила, которого так почитают, ему ответили (если перевести ответ на дозволенный язык): «Он, Ярила, любовь очень одобрял»» (Иванов et al. 1974: 213). Таким образом речь идет о половом акте.

Исследование Вяч. Вс. Иванова и В.Н. Топорова позволяет говорить о существовании «древнего культа Ярилы, имя которого было вытеснено рядом новых мифологических или церковных имен», и его «праславянском прообразе (для которого *jarъ мог быть только эпитетом, но не основным именем)» (Иванов et al. 1974: 214), причем имя Ярилы сближают с Яровитом (Иванов et al. 1974: 184; Рыбаков 1987: 420). «Одобрение» Ярилой «любви», надо полагать, говорит о его покровительстве данной сфере как представителя высших сил. Наконец, сюда можно добавить новые данные, оставшиеся упомянутым исследователям неизвестными. В Ульяновской области зафиксировано упоминание Ярилы в связи с понятием «Бог»: «Праздник-та «Ярилки» называли. «Ярила»-та, наверна, па-стариннаму эта Бог, вот верят в Бога, умрёт - яво праздник пачитают» (Традиционная культура Ульяновского Присурья 2012: 621). А на Тамбовщине в единичной записи (с. Вирятино, 1975 г.) имя Ярила использовано вместо понятия «солнце»: «Ярила фстала на вастоки» (Словарь тамбовских говоров 2001: 196). Эти подробности позволяют дополнить представление о прежнем статусе Ярилы (его прообраза), как одного из статусных божеств славянской дохристианской религии.

Итак, имеется персонаж гипотетически этиологического мифа, проявляющий себя как своеобразный демиург и связанный, судя по имени, с темой сексуальности. В реконструкции получаем фигуру славянского дохристианского божества, также связанного с идеей плотской любви. Наличие у глиняной или соломенной фигуры Ярилы «подчеркнутых признаков мужской силы», его «одобрение (плотской) любви» хорошо согласуется с контекстом, выводимым из подчеркнуто гиперболизированного имени «Иван Переїбан-Переплетипизда». Герой истории как бы авансом наделен гиперсексуальной активностью, что хотя и не получает прямого отражения в сюжете, но все же подразумевается (наличие у него семи дочерей; расправа с лишней вульвой). Нельзя прямо отождествить два этих образа, ввиду недостаточного объема сведений об обоих, однако, если искать среди славянских богов прообраз для предположительно имеющего черты демиурга Ивана из анализируемого текста, то Ярила на эту роль мог бы претендовать.

2.4. Второе действующее лицо в сюжете - довольно таинственная баба Анастасия Сорокопиздасия. Она - яркая квинтэссенция женского начала. Ее второе имя, показывающее Анастасию обладательницей сакрального для славянской традиции числа вульв - сорока (синонима понятия «множество»), - это, безусловно, своеобразный количественный эпитет: подобно тому, как Геката может прозываться 


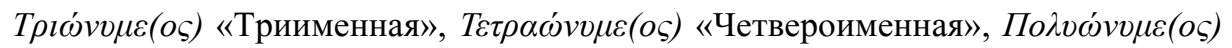
«Многоименная», а Кали - «Четырехрукая» (Девибхагавата-пурана, XII.6.47). Большое количество половых органов у Анастасии - явление того же порядка, что и широко распространенное иконографическое умножение частей тела у божеств некоторых народов индоевропейского происхождения: поликефалия ряда славянских (Триглав, Свентовит, Руевит), отдельных италийских, римских (Янус), кельтских (Луг), фракийских (двух- и трехглавый всадник) и многих индийских Божеств, многорукость богов Индии и греческих великанов-гекатонхейров, а также Фемиды, богини правосудия (названной византийским историком ХІІ в. Никитой Хониатом «многоногой и многорукой»), трехтелость Гекаты и т.д. Анастасия вписывается в этот ряд, что позволяет говорить о высоком статусе ее прообраза.

Собственно говоря, фигура Анастасии не одинока в обладании множеством гениталий. Подобный образ известен русскому - опять же смехоэротическому фольклору: «А у нашея невески не как у людей, // А у нашея невески двенадцать пизд: // Назади пизда, спереди пизда, // На коленях пизда, под коленем пизда, // Пизда в пизде, в прикалитках две» (Русский эротический фольклор 1995: 37), «Mbl по Питеру катались // На кобыле без узды. // На такую блядь нарвались: // Восемь сисек, три пизды» (Озорные частушки 1995: 87). Имеется подобный женский демонический персонаж в индуизме. В «Джайминия-брахмане» (I.62) говорится о брахмане Сумитре, женившемся на демонице, у которой на каждом члене тела была yoni. Стоит отметить также, что обозначение гениталий может включаться в имена-эпитеты богинь. Так, одно из тысячи имен богини Лалиты - Yoni-mudrā «Являющаяся жестом-мудрой Йони» (Тысяча имен Богини Лалиты, № 982). Допуская отождествление Анастасии из «Истории об Иване» с Ягой, впору высказать мысль о непосредственной связи между предполагаемым наличием у Анастасии сорока вульв и таким же числом дочерей у Яги.

Если многоглавость богов, по мысли М. Элиаде, обозначает их божественное всезнание (Элиаде 2002: 35), то множество гениталий Анастасии следует прочитывать сходным образом - как символ ее всезнания и помощи в сфере, всего связанного с женским телесным низом (гинекологии, зачатия, чадородия). Что, собственно, подтверждается самим текстом «Истории об Иване»-Анастасия помогает дочерям Ивана обрести части тел, необходимые для продолжения человеческого рода. Она - исток этой области сакрального женского мира, к ней и надлежит прибегать за помощью с целью исцелить, поправить в случае отклонения от нормы.

2.5. Помочь демиургическому Ивану в его беде (или затее?) может лишь персонаж, близкий ему по статусу. Демиург за тем, что не умеет сам, не пойдет на поклон к кому-то, кто статусно ниже его. Это видно на примере дуалистических легенд, где Бог регулярно прибегает к помощи своего антипода Сатаны, почти ни в чем ему не уступающего. Следовательно, Анастасия - не простая продавщица вульв, и даже не ведьма, могущая их изготовить, но отображение богини, связанной, быть может, с деторождением. Отсюда такое количество вульв, отразившееся в ее прозвище. Имя Анастасия, думается, здесь также не случайно и связано с почитаемой в народе св. Анастасией Узорешительницей, к которой женщины обращались для удачных 
родов. Св. Анастасия, вероятнее всего, переняла черты какой-то из языческих богинь славян (Успенский 1982: 137), подобно тому, как в образе св. Параскевы (Пятницы) «находит отражение дохристианский культ богини Мокоши» (Толстая 2009: 383). Отголоски прежнего поклонения женским языческим божествам можно видеть в периодических рецидивах старых верований, постоянно обновляющихся в рамках новой религии: «Да по погостам и по селам и в волостях лживые пророки, мужики и жонки, и девки и старые бабы, наги и босы, и волосы отрастив, распустя, трясутся, и убиваются, а сказывают, что им является св. Пятница и св. Анастасия, и велят им заповедывать канун засвечивати; они же заповедывают христианом в среду и в пятницу ручного дела не делать, и женам не прясть, и платья не мыть, и камения не разжигать, и иные заповедывают богомерзкие дела творить, кроме Божественного писания» (Стоглав. Вопрос. 21). Образ св. Анастасии (от греч.

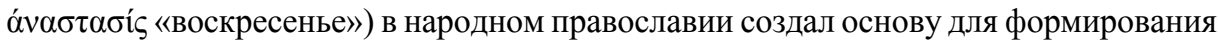
культа св. Недели (персонификации воскресного дня), причем сакральный статус ее необычайно высок: по представлениям гуцулов, «неділя - то Матка Божа» (Белова 2004: 391, 392). Божья мать эпохи двоеверия - пережиток Матери богов времен язычества. Что Богородица, что св. Неделя - покровительницы женской доли и женских работ.

Св. Неделя (Анастасия) народного православия - фигура одновременно благая и пугающая. К тем, кто ее чтит, она милостива и дарует добрую долю. В словацкой сказке, записанной Боженой Немцовой, герою помогает svatá Nedělka - дает ему добрые советы и необходимые вещи, а также волшебного коня, а затем она же и оживляет убитого героя водой, принесенной им ранее: чеш. Ihned tělo namazala nejprve mrtvou vodou a potom je složila, polila vodou živou, a Vit'a z kosi zívnula vstal živ a zdráv (Božena Němcová. Slovenské pohádky a pověsti. O Vít’azkovi). Помощь ее мужскому персонажу вполне сравнима с «Историей об Иване», где Анастасия помогает также мужчине (хотя, в конечном итоге, девушкам). Тех же, кто нарушает запрет на женские работы в воскресенье - посвященный ей день, она пугает страшным образом: «подбрасывает в хату конские головы или тела мертвецов» (Народная библия 2004: 95), притаскивает с собой гроб для виновницы: «Уся в белом пришла и труну тягне, каже: «Хфатит, вилазь, - каже, - наробила, фатить»» (Павлова 1985: 68). Либо жестоко наказывает: в белорусском предании к девушке, прявшей в воскресенье, приходит св. Нидзеля и дарит ей свои бусы, вешая их на шею, а когда она ушла, «с mых пащеркаў зрабиусе велизны уж и задушыу тую дзеўчыну» (Federowski 1897: 139). Чаще же всего она предупреждает нерадивых прях, явившись им в обезображенном виде, приобретенном по их вине: «Пряхам Неделя говорит, что они прядут не лен, как им кажется, а прядут ее волосы, и указывает на свою изорванную косу; молотящим на току она показывает свое белое тело, покрытое во множестве синяками, и говорит, что это они так цепами ее тело калечат» (Rulikowski 1853: 168), блр. «посэчана, порубана тая жэншчына, $i$ з ее просто, ну, крой відна» (Традыцыйная мастацкая культура беларусаў 4/2: С. 471), «аннож прыходзиџь асоба ўся ў сребры и золащи прыбрана аж зехащиць на йой. Зотым разхилайе тую адзежу и паказаўвае сваё цело на адных ранах пасечано, 
парубано, пакручано свердлам, долатам падоўблено, галками папорано, киями пабито» - «гэто ўвся недзелищьная ваша работа, бо вы мине, Нидзели, ни шануеце» (Federowski 1897: 138). Либо приходит облаченная, как смерть, во все белое: «Недиля пришла така у билом, висока, страшна», «Уся в белом пришла», «у билом, висока, страшна» (Павлова 1985: 68), блр. «неякаясь асоба у бели» (Federowski 1897: 139), хорв. «Святая Неделя - женщина в белом. И поныне дети видят св. Неделю, что стоит на перекрестке или сидит на изгороди, как женщина, облаченная в белое» (Lovretić 1902: 141). Белорусское няделька в значении «ведьма» (Судник et al. 1978: 126) позволяет связывать фигуру св. Недели с ведьмой Ягой. Но народный анекдот не знает пощады и превращает образ могущественной и трагичной Анастасии-Недели в вычурно эротизированную бабу Анастасию.

В ведении языческого прототипа св. Недели и бабы Анастасии было все, связанное с женским телом. В аспекте любовной магии, деторождения девушки и женщины могли обращаться к своей покровительнице за помощью, принимая во внимание ее женскую природу, ее связь с кем-либо из богов, от которого она затяжелела и родила. В силу этого на, в прямом смысле этого слова, женском начале богини-покровительницы акцентируются описания ее в сказочных текстах, наследующих древним мифам ${ }^{8}$, и в народной вышивке, сохраняющей архаичные сюжеты. Языческая эпоха, иначе относившаяся к сексуальности и демонстрации половых органов, наделяла соответствующими чертами характера и своих божеств.

Так, свое женское начало в сказках активно и натуралистично демонстрирует Яга, в каковой определенно угадывается прежняя богиня: «Из избушки выскочила Баба-Яга костяна нога, жопа жилена, м... мылена» (Ончуков 1996, № 8), «лежит баба-яга костяная нога, из угла в угол, титьки через грядку висят» (Афанасьев 1957, № 224). Приходящему к ней герою истории она подает на стол блюда, но весьма своеобразно: «Старушка перднула - стол подернула; бзднула - щзей плеснула; на карачки стала - калачиков достала; титьками потрясла - чашки, ложки принесла; с...ль свищет - солонку ищет» (Русские сказки и песни в Сибири 2000: 333), «скочила, пёрнула, столп отдёрнула и сителем потресла, и говединки принесла» (Соколовы 1999: 565), «Она сейчас п...ула - стол поддёрнула, б...ла - штей плеснула, ногу подняла и пирог подала, титечкам потресла и молочка поднесла, ножки возняла и ложки подала» (Зеленин 1997: 98), «Баба-Яга пернула, стол поддернула, безнула, щуей плеснула, на коряки встала, калачей достала,

\footnotetext{
8 Канва сказки может быть как порождением мифологического сюжета, так и самим мифом, переродившимся в сказку: «Собственно сказочная семантика может быть интерпретирована только исходя из мифологических истоков. Это всё та же мифологическая семантика, но порой уже оторванная от племенных верований и принявшая некоторую поэтическую условность, а также испытавшая известный сдвиг от космического к социальному и индивидуальному» (Мелетинский 1998, 17). В другой своей работе Е.М. Мелетинский говорит про «историческое стадиальное соотношение между мифом и сказкой» и «архаический и синкретический характер мифа, в принципе предшествующего волшебной сказке» (Мелетинский 1995, 56). Можно также привести лапидарное высказывание В.Я. Проппа, читающееся как формула: «когда герой теряет свое имя, а рассказ теряет свой сакральный характер - миф и легенда превращаются в сказку» (Пропп 1998: 227).
} 
титьками потрясла, молока принесла» (Сказки Шадринского края 1995: 30)9. Ее позы весьма откровенны (если бы не контекст): «сидит Баба-яга - одна нога у ее на полке, а друга на грядке» (Зеленин 1997, № 67), «в изобке сидит баба-яга костяная нога; сама на стуле, нос в потолок, одна нога в правый угол, а другая в левый» (Афанасьев 1957, № 225). И она же вполне покровительствует женской доле - наделяя присланную или попавшую к ней девушку приданым к свадьбе (Афанасьев, № 102: 155), а атрибуты прядения, постоянно сопутствующие описанию Яги, указывают на ее отношение к прежней богине судьбы: «Прядение бабы-яги - знак ее власти над судьбой, дара распознавать будущее» (Русский демонологический словарь 1995: 30). При том, что имя богини Мокоши возводится к корню *mokos «прядение», при лит. makstýti «плести», mèksti «вязать» (Иванов et al. 1990: 367; Этимологический словарь славянских языков 1992: 133). Специально о связи Яги и Мокоши см.: (Becer 1990: 114-140).

Женская фигура, демонстрирующая свое лоно, так же, как это представлено на европейских скульптурных изображениях женщин (Sheela na Gig), имеется на русских вышивках: «В вышивках на полотенцах, кроватных подзорах и на кокошниках широко представлены композиции с женской фигурой в центре и оленями по сторонам её. Женщина нередко показана в позе роженицы с раскинутыми руками и согнутыми и тоже раскинутыми в стороны ногами. Существует много вариантов этого не очень пристойного сюжета. Натуралистичность ситуации старались скрыть то множеством дополнительных деталей, то предельной стилизацией и упрощением образа, но для нас ценно то, что, невзирая на эти ухищрения вышивальщиц, мы во многих случаях можем разглядеть основу архаичного образа - рожающую женщину» (Рыбаков 1987: 477). Подобные «роженицы» (по терминологии Б. А. Рыбакова), вполне вероятно, были своеобразным изображением богини, связанной с деторождением. Традиция не сохранила пояснений, с какой целью такой образ вышивался, но, безусловно, ритуальная или магическая причина к тому была, и в изображении оказывалось принципиально важным показать размещенную в центре композиции женскую фигуру именно в такой натуралистической позе. По аналогии с тем, что женщины просили свою небесную покровительницу помочь в родах ${ }^{10}$, можно допустить, что изображенное в вышивке разверстое лоно богини было призвано облегчить роды земным женщинам. Отголоски некогда вызывающего и нескромного образа покровительницы женщин, ведающей сокровенным женским началом, могли породить в мужской субкультуре комичную фигуру сатирической Анастасии, по сходной цене продающей разнотипные вульвы.

2.6. У Анастасии можно приобрести женские гениталии любого, судя по всему, вида («руду, сиду і всяку»). Их она выносит целую «мірку». Славянский фольклор

\footnotetext{
9 Что отозвалось и в частушках нескромного содержания: «У старухи у старой // Два завода у одной: // Спереди вино течет, // Сзади крендели печет» (РЭФ 1996: 494), «Плями, моя тетка, // Спереди бородка, // Между ног - чугунок, // Сзади сковородка» (Волков 1999: 328).

10 Заговор, читаемый повитухами: укр. «Іде пречистая Божая Маті, іде горою, несе ключі з собою, стричає їх сам Господь і поутає: «Куди ідеш, Божая маті?» - «Іуу до Уляни дєтєй рожаті, костей растворяті, на свєт дєтей пускати» (Боряк 2009: 136).
} 
вроде бы не знает мифологического персонажа, у которого бы имелся целый запас отдельных вульв. Но исток такого представления, как кажется, можно обнаружить.

Женское лоно в фольклоре и народной лексике табуированно обозначается через эвфемизмы, нередко связанные с животным миром ${ }^{11}$. Особняком от этого весьма широкого ряда образов стоит уподобление женских гениталий земноводным (жабе, лягушке) $)^{12}$, что связано с общеславянским отнесением лягушек и жаб к любовно-брачной символике. Так, среди сербских табуированных обозначений вульвы встречается жаба, жапка, жапче (Златковић 2001: 13, 14). Сравнение с земноводным отмечено в частушках: «А пиздушка, как лягушка, // Мокрая, холодная» (Волков 1999: 154). И нашло воплощение в народной магии: «В Ярославской губ. старые девы, чтобы выйти замуж, находят в болоте лягушку и, приседая, стараются попасть по ней с размаху голым задом» (Гура 1997: 382). В боснийских и хорватских соромных сказках во влагалище женщины на ночлег укрывается жаба: «А я залезу к ней в пизду, - подхватила жаба. - Там мокро, тепло и уютно!», «Жаба, любившая всё сырое, решила скоротать ночь у нее в пизде» (Краусс 2009: $346,347)$. В белорусской жнивной песне, украинской и словацкой частушках описана ситуация проникновения жабы в тело девушки: блр. «Як была я молода, дак была я резва, // Пошла жать, легла спать - жаба улезла» (Романов 1885: 246), укр. «Як була я молода, // То була я різва: // Сіла срати середь хати - // Жаба в пизду влізла!» (Folklore de Ukraine 1898: 126-127), словац. Anička konope močila, // Žaba jej do pičky skočila, // Neboli konope, lež boli len, // Vyskoč mi, žabička, z pičky ven (Krekovičova 2000, 387). Тот же образ использован и в современной русской частушке: «К гинекологу пришла // Дряхлая старушка: // Помотри-ка, миленький, // Что там за лягушка? (Бобров 2007: 168). Аналогичное представление бытовало у других индоевропейских народов. М. Гимбутас отмечает, что до ХХ в. европейские крестьяне верили, что жаба является знамением беременности. Есть много свидетельств, как из фольклора, так и из истории, греческих, римских и более поздних, что жаба рассматривалась как эпифания богини или её матки. Отсюда и вера в «странствующее лоно», отмеченная в древнеегипетских и греко-римских источниках, а также в современном фольклоре. Гиппократ и Платон описывали матку как животное, способное двигаться во всех направлениях в брюшном отделе (Gimbutas 1989: 251). По литовским поверьям, «матка в животе бабы живая, в виде лягушки» (Петкевич 1911: 187), «В Пруссии литовцы верили, что в теле человека находится существо, наподобие жабы, которое вызывает болезни и смерть.

\footnotetext{
${ }^{11}$ С преобладанием птичьих названий: рус. куница, киска, кошечка, ласточка, голубка, курочка, соловей (Волков 1999: 746-748), курица, соловей, баран, птичка (РЭФ, 466), блр. авечачка, вылра, зязюлька, курка, курыца, салавей, пташачка, ияцерка, чорна куна (Белорусский эротический фольклор 2006: 365-366), укр. пташечка (УСП, № 175), курка, курочка (Криптадії Федора Вовка 2018: 99, 106), кунка, тетеря (Бандурка 2001: 31, 82), серб. врана, зајек, квачка «курица», ластавица, лисица, маче, маченце, мачка «кошка», мечица, мечка «медведица», пиле, пиленце «цыпленок», риба, рибица, рибле, рибленще, чавка «галка» (Златковић 2001, 13), босн. štuka «щука», šaran «карп» (Краусc 2009: 418), болг. петле «петух», сврачак «сорока», кукувица «кукушка» (Митология на човешкото тяло 2008: 23).

12 Таких примеров в научной литературе сведено мало, поэтому, пользуясь возможностью, стоит пополнить их число.
} 
Латыши считают, что «в каждом человеке - без различения пола - сидит матка, от сохранности которой завесило его здоровье. Она имеет - как жаба - четыре лапы, а плечи размеров большой ящерицы. Раздразненная или движением со своего места вытесненная, обхватывает своими лапами внутренности человека и сильным сжатием их вызывает болезни» (Biegileisen 1929: 7). Латышские песни, как предполагает С. И. Рыжакова, сохранили символическое сближение «жаба - вульва»: «У меня была одна зеленая жаба, пять лет выкармливаемая. // Соседские парни жестокие были, съели мою жабу, // Съели мою жабу, думая, что (это) раки» (Рыжакова 2002: 185). В Баварии верили, что «матка в виде жабы вылезает изо рта женщины во время сна, чтобы выкупаться» (Плосс 1995: 263). Сюда же тяготеет известное славянам представление о вредоносной лягушке / жабе, находящейся внутри человека, что отражено в выражении рус. жаба душит / давит, блр. жаба душыщь «об испытываемом кем-либо чувстве жадности, зависти», болг. жаби ми къеркат в стомаха «об урчании в животе», а также, возможно, наименовании ряда болезней (изначально, внутренних) человека и скота: рус. ряз. жаба «ангина» (Словарь современного русского народного говора 1969: 162), арх. «болезнь, которую напускают, наводят; порча», курск. жабица «болезнь свинка», туль. «болезнь горла», тоболь. жабище «болезнь (какая?)», новг. жабка «воспаление языка и слизистой оболочки рта», «воспаление желез», «опухоль на шее, щеке» (Словарь русских народных говоров 1972: 49, 50), блр. витеб., могил. жаба «ангина» (Романов 1891: 88), «болячка на языке у коровы» (Varłyha 1970: 171), минск. жаба сухая «ангина», жаба мокрая «стоматиты» (Шатэрнік 1929: 92), жабка «воспаление слизистой оболочки рта у грудничка» (Слоўнік гаворак цэнтральных раёнаў Беларусі 1990: 131), гродн. грудная жаба «сердечная болезнь, стенокардия» (Цыхун 2014: 70), укр. жаба «ангина», грудна жаба «сердечная болезнь» (Словник української мови 1971: 500), буковин. жаба, жєба, жяба «сердечная болезнь» (Словник буковинських говірок 2005: 107), поль. żaba «ангина», «стоматит», «болезнь скота», żabka «болезнь (у детей)», «болезнь у коней» (Słownik gwar polskich 1911: 431, 432), кашуб. žaba «катаракта», «желудочная боль», «название ряда болезней скота» (Sychta 1973: 262), с.-хорв. žabice «свинка», «лимфаденит», жаба «дифтерит», «стоматит», «болезнь на ноге» (Речник српскохрватског књижевног и народног језика 1968: 269), жабина «ангина», болг. жабища, зажабица «опухоль под языком, болезнь коров» (Журавлев 2005: 608). В Чехии лечение ангины сопровождалось заговором: Žabo, žabice, krokvo, krokvice, jsi-li z zř́ldla, vyjdi z hrdla, jsi-li z vody, vyjdi z huby, jsi-li z studnice, sejdi z sanice «Жаба, лягушка, квакушка, квакушка, если ты из источника, выйди из горла, если ты из воды, выйди из рта, если ты из колодца, выйди из (нижней) челюсти» (Вельмезова 2004, № 37).

Представление это в разных его вариациях своеобразным образом материализовалось как в официальном религиозном искусстве: «Устоявшимся типом в романской и готической скульптуре, изображаемым также в более позднее время в «Страшном Суде», был довольно отталкивающий образ обнаженной женщины, груди и гениталии которой пожирают жабы и змеи» (Холл 1996: С. 465), так и в бытующей в народе ритуальной практике поднесения женщинами в дар церкви 
вотивов для исцеления бесплодия - восковые и чеканенные из металла фигурки жаб (Плосс 1995: 263). Данное обыкновение известно у немцев, у западных и южных славян (Словения, Хорватия, Сербия) (Плотникова 1995: 443). Так, у сербов бесплодные женщины покупали восковые вотивы, называемые матерница, внешне (голова, положение конечностей) напоминающие жабу (Филиповић 1933: 99). Ю.Е. Арнаутова уточняет: «С раннего средневековья известны, например, символические изображения матки в виде жабы, в которых следует видеть скорее влияние античной медицины» (Арнаутова 1995: 162). Опираясь именно на эту символику, в русском фольклоре инициация колдуна / ведьмы уподобляется родам, в ходе которых на свет рождается новый магический специалист - для этого неофит должен проникнуть внутрь огромной жабы (оказаться съеденным ею) и быть извергнутым обратно через рот или задний проход: «один крестьянин захотел стать колдуном и обратился за помощью к опытному колдуну. Тот велел в двенадцать часов ночи придти к нему в ригу. Мужик пришёл; колдун велел стать на икону спасителя. Тот встал, а колдун стал читать что-то. Из риги выскочила лягушка. Колдун перестал читать и говорит мужику: «Теперь ты должен пролезть через эту лягушку». Крестьянин, усльшиав это, испугался и убежал», «Видит: на лавке сидит громадная лягушка, больше человеческого роста, глаза горят. /.../ Бабы приказали вновь пришедшей раздеться донага, и колдунья велела ей лезть в пасть лягушки. Как только сказала она это, лягушка прыгнула с лавки и разинула пасть, а пасть стала такая большая, что поезжай туда хоть на тройке. Влезла туда баба и вылезла через задний проход; так она сделала по приказанью колдуньи три раза. /.../ Колдунья её спрашивает: «Всёли ты видела, всё ли теперь знаешь?» Та сразу же всё поняла и стала с тех пор колдовать», «Вылезла голова, вроде лягушки, а пасть более ведра. «Шутыл» его туда втиснули. Он чуть не задохся. Потом голова его изрыгнула, и её стало рвать» (Никитина 1994: 185, 186), «Чтобы научиться портить людей, они должны были ночью прийти в баню. Там выпрыгнет жаба. Каждый должен влезть к ней в пасть, перевернуться там и выйти обратно» (Мифологические рассказы и поверья Нижегородского Поволжья 2010: 219). Сравни также устойчивую связь между лягушкой и матерью (той, кто рождает): рус. «Не бей лягушку -мать умрет!» (Морозова et al. 2007: 75), укр. «Жьибу не мож убити, бо такому умерла би мама» (Шухевич 1908: 273), у сербов существует поверье, «что у ребенка умрет мать, если он убьет жабу» (Kajmaković 1974: 81).

Восточнославянскому фольклору хорошо известен женский мифологический персонаж, который одновременно связан с рядом моментов, озвученных в приведенных параллелях: 1) с темой инициации (Топорков 1992: 114-118), обладает колдовскими способностями, 3) имеет в своем хозяйстве массу лягушек, в традиции служащих метафорой матки. Мы вновь возвращаемся к образу Бабы Яги. Одним из трудных заданий Яги, представляющих настоящее испытание для нервов попавших к ней девушек, является требование вымыть (попарить) «ее деток»: «A детки ее были лягушки» (Багизбаева 1979: 269), «Подошла падчерица и видит /.../ всякой нечисти полньм-полно: и лягушки, и змеи, и ящзерицы, и ужи» (Морохин 1994: 104), «Это мои дети - мыши и лягухи» (Фольклор старообрядцев Литвы 2007: 
222), «А дети у Бабы-Яги лягушки да, мышии да» (Архангельские сказки: 74), «Байну затопила. Егибиха наносила всяких скакуш да лягуш и велела вымыты» (Никифоров 1961, 147), «Поди в баню! Я сейчас пришлю к тебе своих детей!» Она и пошла в баню. Вдруг видит, что к ней в баню ползут червяки, лягушки, крысы и всякие насекомые» (Худяков 2001: 57), «Баба-яга и говорит: «Возьми моих детей, попарь». Она взяла их, в кувшин положила. А там лягушки, таракань, козюли» (Эрленвейн 2005: 63-64), «Под лавкой, в деловушке, дети скакухи (лягушки) да жигалюхи (ящерицы)» (Ончуков 1996: 274), “Старуха Маше дала корзинку и сказала: «На-ко, вымой моих детушек». Понесла Маша корзинку в байню и тряхнула ее на полок, а там были гадьи: жилюхи, лигухи и все ползучие червячки» (Сказки Заонежья 1985: 85). Это, как видим, устойчивый элемент, и если прочая живность может меняться, то лягушки упоминаются во всех случаях. Сюда же может относиться представление о том, что колдуны и колдуньи держат под домом емкости с подобной живностью, для напускания порчи: «в туеске, говорит, закрыты в туеске в подполе стоят пошибки-пауты (оводы). В туесок набьют их там, а потом их пускают везде. Да! Говорят, будто лягушками, мьшиами, у кого это, ящерицей пустят - мучается человек» (Христофорова 2013: 121). В таком виде в русской сказке тело покидает колдовство (порча): «из ее рта лягушки, змеи всякие выходят (видать была заколдованная)» (Бараг 1979: 159), «Как выпил дед-от отвар, так его и скрутило, и скорчило и изо рта он лягушку выхаркнул. Поймали эту лягушку, да в печ сунули. Так вот и выгнали нечистого духа» (Мифологические рассказы и поверья Нижегородского Поволжья 2010: 135).

Связь Яги с инициацией, в ходе которой изображается новое рождение, позволяет сделать предположение, что обитающие в ее жилище земноводные, поименованные Ягою своими детьми, могут отсылать к менее прозаической их интерпретации, позднее оставленной или утерянной. Лягушки Яги могут быть понимаемы как метафора совокупности всех женских начал, находящихся под покровительством языческой богини, чье место в сказочном жанре заняла Баба Яга. Только у нее прототип Ивана мог бы заполучить необходимое количество вульв для своих дочерей.

2.7. Наконец, еще один принципиально важный момент, дающий подсказку в пользу этиологического генезиса «Истории об Иване». Упоминаются дочери Ивана, но нет ни слова об их матери. Будь она в наличии, то кому, как не ей помогать дочерям в столь интимном деле? Искать решение проблемы, идти на поклон к колдунье, прилаживать полученные у нее вульвы на полагающееся место? Однако этим занимается отец. Матери нет даже для того, чтобы дать ему совет. Следует полагать, что ее не просто нет в истории, но и никогда не было вообще, поскольку перед нами описана ситуация времен творения, где действуют исключительно мужские персонажи (Бог и Черт, дед и внук: У истоков мира 2014, № 1: 15). Дочери Ивана - первые женщины на белом свете, созданные демиургом - собственно, фольклорным Иваном. Он не мог создать их «по своему образу и подобию», в результате чего творения получились с недочетом. Дочерями история их называет образно, поскольку отношения между творцом и созданными им людьми вполне поддаются описанию как родственные. 
Полагаю, приведенных данных достаточно, чтобы всерьез рассматривать «Историю об Иване» как отголосок этиологического мифа, сохранившийся в смехоэротической интерпретации. Имеются все основания считать возможной для прообразов обоих главных действующих персонажей реконструкцию в качестве высокостатусных персонажей дохристианской мифологии - Бога-демиурга («Бог /.../ девчонок наградил: // Меж ног дырку прорубил!») и женской фигуры, переродившейся в позднейшую сказочную Ягу. В самом общем виде можно предположить следующую форму сюжета мифа с их участием. Демиург (Род?) создает (порождает) первых мужчин и женщин, но у них нет половых органов (чтобы продолжить человеческий род). Неизвестным нам образом он исправляет этот недочет в отношении мужчин, однако не может сделать того же в отношении женщин. Для этого он отправляется за реку-границу к независимо от него существующей богине (наподобие судьбы-Мокоши), и та обучает его, как помочь женщинам (возможно, просто прорубив промежность топором). С тех пор люди стали размножаться.

Остается без ответа лишь один вопрос: зачем баба Анастасия дала Ивану лишнюю вульву? Она ему ни к чему: дочерей всего семь и восьмую девать было некуда. Это едва ли не пролог к варианту с «лишней» дочерью Адама и Евы, оставшейся без пары (Легенди та перекази 1985: 47). «История об Иване», как думается, утратила часть, где фигурировали мужчины, предназначенные в пары семи дочерям Ивана. Можно предположить, что Анастасия знала, чем все это обернется, и сделала свой подарок намеренно. Капкан, в который герой истории, по закону жанра, незамедлительно угодил. Что, впрочем, не привело к трагедии одиноких женщин, но обернулось на пользу. Был ли повод к такому поступку у бабы Анастасии, какие цели могла она преследовать - всего этого мы, почти наверняка, никогда уже не узнаем, поскольку исчез миф, лежащий в основе соромной байки об Иване.

\section{ЛИТЕРАТУРА}

Народная поэзия Арзамасского края, 2002: Сказки. В двух книгах, Книга 2, Арзамас: Арзамасский государственный педагогический институт. [Narodnaja poezija Arzamasskogo kraja, 2002: Skazki. V dvuh knigah, Kniga 2. Arzamas: Arzamasskij gosudarstvennyj pedagogičeskij institut.]

Арнаутова, Ю. Е., 1995. Чудесные исцеления святыми и «народная религиозность» в средние века. Одиссей. Человек в истории. С. 151-169. Москва: Издательство «Наука». [Arnautova, Ju. E., 1995: Čudesnye iscelenija svjatymi i «narodnaja religioznost'» v srednie veka. Odissej. Čelovek v istorii, P. 151-169. Moskva: Izdatel'stvo «Nauka».]

Афанасьев, А. Н., 1957: Народные русские сказки, Т. 1-3 Москва: Государственное издательство художественной литературы. [Afanas'ev, A.N. , 1957: Narodnye russkie skazki, T. 1-3. Moskva: Gosudarstvennoe izdatel'stvo hudožestvennoj literatury.]

Афанасьев, А. Н., 1997: Народные русские сказки не для печати, заветные пословицы и поговорки. Москва: Научно-издательский центр «Ладомир». [Afanas'ev, A. N., 1997: Narodnye russkie skazki ne dlja pečati, zavetnyje poslovicy i pogovorki. Moskva: Naučno-izdatel'skij centr «Ladomir».] 
Акты исторические, 1841. Т. 3. № 92, Санкт-Петербург: В Типографии II-го Отделения Собственной Е. И. В. Канцелярии. [Akty istoričeskie, 1841. Т. 3, № 92, Sankt-Peterburg: V Tipografii II-go Otdelenija Sobstvennoj E. I. Veličestva Kanceljarii.]

Архангельские сказки, 2002: Из материалов лаборатории фольклора Поморского университета. Составитель Н.В. Дранникова. Архангельск: Поморский государственный университет имени М. В. Ломоносова. [Arhangel'skie skazki. Iz materialov laboratorii fol'klora Pomorskogo universiteta, 2002. Edit. N. V. Drannikova. Arhangel'sk: Pomorskij gosudarstvennyj universitet im. M. B. Lomonosova.]

Багизбаева, М., 1979: Фольклор семиреченских казаков. Ч. ІІ. Алма-Ата: Мектеп. [Bagizbaeva, M., 1979: Fol'klor semirečenskih kazakov. Č. II. Alma-Ata: Mektep.]

Бандурка. Украӥньскі сороміџькі пісні, 2001. Київ: Дніпро. [Bandurka. Ukrajin’ski soromic'ki pisni, 2001. Kijev: Dnipro.]

Бараг, Л. Г., 1979: Новая запись сказки о святом Николе-поручителе. Фольклор народов РСФСР. Межвузовский научный сборник. Bып. 6. Уфа: Издательство Башкирского государственного университета. [Barag, L. G., 1979: Novaja zapis' skazki o svjatom Nikole-poručitile. Fol'klor narodov RSFSR. Mežvuzovskij naučnyj sbornik. Vyp. 6. Ufa: Izdatel'stvo Baškirskogo gosudarstvennogo universiteta.]

Бахтин, М. М., 1965: Творчество Франсуа Рабле и народная культура Средневековья и Ренессанса. Москва: Издательство «Художественная литература». [Bahtin, M. M., 1965: Tvorčestvo Fransua Rable i narodnaja kul tura Srednevekovja i Renessansa. Moskva: Izdatel'stvo «Hudožestvennaja literatura.]

Белова, О. В. Неделя (персонаж), 2004: Славянские древности. Этнолингвистический словарь. T. 3 (Круг - Перепелка), Москва: Международные отношения. [Belova, O. B. Nedelja (personaž), 2004: Slavjanskie drevnosti. Etnolingvističeskij slovar’. T. 3 (Krug-Perepelka). Moskva: Meždunarodnye otnošenija.]

Березкин, Ю. Е., Дувакин, Е. Н., 2019: Тематическая классификация и распределение фольклорно-мифологических мотивов по ареалам. Аналитический каталог (http:// www.ruthenia.ru/folklore/berezkin/intro.html). [Berezkin, Ju. E, Duvakin, E. N., 2019: Tematičeskaja klassifikacija i raspredelenije fol'klorno-mifologičeskih motivov po arealam. Analitičeskij catalog (http://www.ruthenia.ru/folklore/berezkin/intro.html).]

Березович, Е. Л., 2010: Русская топонимия в этнолингвистическом аспекте. Мифопоэтический образ пространства. Москва: Издательство «Индрик». [Berezovič, E. L., 2010: Russkaja toponimija $v$ etnolingvističeskom aspekte. Mifopoetičeskij obraz prostranstva, Moskva: Izdatel'stvo «Indrik».]

Бобров, А., 2007: Частушка московская: бытовая, плясовая, эротическая, озорная. Москва: Алгоритм. [Bobrov, A., 2007: Častuška moskovskaja: bytovaja, erotičeskaja, ozornaja. Moskva: Algoritm.]

Боганева, Е., 2008: Современные народно-библейские нарративы белорусов: бытование, контекст, параллели (На материале сюжетов о сотворении мира и первых людей). Фольклористика в контексте наук о традиционной духовной культуре. Москва: Государственный республиканский центр русского фольклора. [Boganeva, E., 2008: Sovremennyje narodno-biblejskie narrativy belorusov: bytovanie, kontekst, paralleli ( $\mathrm{Na}$ material sjužetov o sotvorenii mira i pervyh ljudej). Fol'kloristika $v$ kontekste nauk o tradicionnoj duhonoj kul ture. Moskva: Gosudarstvennyj respublikanskij centr russkogo fol'klora.]

Боряк, О., 2009: Баба-повитуха в культурно-історичній традиції українців: між профанним i сакральним. Київ: Інститут мистецтвознатства, фольклористики та етнології ім. Рильського. [Borjak, O., 2009: Baba-povytuha v kul'turno-istoryčnij tradyciji ukrajinciv: 
miž profannym i sakral'nym Kijev: Institut mystectvoznavstva, fol'klorystyky ta etnologiji im. Ryl's'kogo.]

Белорусский эротический фольклор, 2006 (Сост. Т. В. Володина, А. С. Федосик). Москва: Научно-издательский центр «Ладомир». [Belorusskij erotičeskij fol’klor, 2006 (eds. Т. V. Volodina, A. S. Fjadosik). Moskva: Naučno-izdatel'skij centr «Ladomir».]

Вельмезова, Е. В., 2004: Чешские заговоры. Исследования и тексты. Москва: Издательство «Индрик». [Velmezova, E. V., 2004: Češskie zagovory. Issledovanija i teksty. Moskva: Izdatel'stvo «Indrik».]

Веселовский, С. Б., 1977: Акты писиового дела (1644-1661 г2.). Москва: Издательство «Наука». [Veselovskij, S. B., 1977: Akty piscovogo dela (1644-1661 gg.). Moskva: Izdatel'stvo «Nauka».]

Волков, А. Д., 1999: Заветные частушки из собрания А.Д. Волкова. В 2 m. Т. 1. Эротические частушки. Москва: Научно-издательский центр «Ладомир». [Volkov, A. D., 1999: Zavetnyje častuški iz sobranija A.D. Volkova. V 2 t. T. 1. Erotičeskie častuški. Moskva: Naučno-izdatel'skij centr «Ladomir».)

Володарский, Я. Е., 1970: Вологодский уезд в XVII в. (К истории сельских поселений). Аграрная история Европейского Севера СССР. Вологда: Вологодский государственный педагогический институт. [Volodarskij, Ja. Е., 1970: Vologodskij uezd v XVII v. (K istorii sel'skih poselenij). Agrarnaja istorija Evropejskogo Severa SSSR. Vologda: Vologodskij gosudarstvennyj pedegogičeskij institut.]

Гальковский, Н. М. , 1913: Борьба христианства с остатками язычества в Древней Руси. T. 2. Москва: Печатня А. И. Снегиревой. [Gal'kovskij, N. М., 1913: Bor'ba hristianstva s ostatkami jazyčestva v Drevnej Rusi. T. 2. Moskva: Pečat'nja A. I. Snegirevoj.]

Гура, А. В., 1997: Символика животных в славянской народной традиции. Москва: Издательство «Индрик». [Gura, A. V., 1997: Simvolika životnyh v slavjanskoj narodnoj tradicii. Moskva: Izdatel'stvo «Indrik».]

Гурякова, Л. Г., 2011: Родники Киржачской земли. Владимир: Калейдоскоп. [Gurjakova, L. G, 2011: Rodniki Kiržačskoj zemli. Vladimir: Kalejdoskop.]

Девибхагавата-пурана. Книга двенадиатая (Перевод с санскрита, предисловие и комментарий А. А. Игнатьева), 2011. Калининград: Санатана дхарма. [Devibhagavata-purana. Kniga dvenadcataja (Perevod s sanskrita, predislovie i kommentarij A. A. Ignat'eva), 2011. Kaliningrad: Sanatana dharma.]

Дериглазов Р. А. (сост.), 1993: Я частушек много знаю. Новгород: Литера. [Deriglazov, R. A. (ed.), 1993: Ja častušek mnogo znaju. Novgorod: Litera.]

Дзічячы фальклор. Зборнік фальклорных матэрыялаў, 2006. Мінск: Беларускі дзяржаўны педагагічны універсітэт імя Максіма Танка. [Dzicjačy fal'klor. Zbornik fal'klornyh materyjalav, 2006. Minsk: Belaruski dzjaržavny pedegagičny universitet imja Maxima Tanka.]

Жаворонков, А. 3., 1956: Анекдотическая сказка А. С. Пушкина. Ученые записки Новгородского государственного педагогического института. Том 1. Историко-филологический факультет. Bыn. 1. Новгород: Новгородский государственный педагогический институт. [Žavoronkov, A. Z., 1956: Anekdotičeskaja skazka A. S. Puškina. Učenye zapiski Novgorodskogo gosudarstvennogo pedagogičeskogo instituta. T. 1. Istoriko-filologičeskij fakul'tet. Vypusk 1. Novgorod: Novgorodskij gosudarstvennyj pedegogičeskij institut.]

Живой родник. Донские загадки, пословицы и поговорки, собранные С. Н. Земиовым, 1985. Волгоград: Нижне-Волжское книжное издательство. [Živoj rodnik. Donskie zagadki, poslovicy i pogovorki, sobrannye S. N. Zemcovym, 1985. Volgograd: Nižne-Volžskoe knižnoe izdatel'stvo.] 
Журавлев, А. Ф., 2016: Эволюиия смыслов. Москва: Издательский дом ЯСК. [Žuravlev, А. F., 2016. Evoljucija smyslov. Moskva: Izdatel'skij dom JASK.]

Журавлев, А. Ф., 2005: Язык и миф. Лингвистический комментарий ктруду А. Н. Афанасьева «Поэтические воззрения славян на природу». Москва: Издательство «Индрик». [Žuravljev, A. F., 2005: Jazyk i mif. Lingvističeskij kommentarij k trudu A. N. Afanas'eva «Poetičeskie vozzrenija slavjan na prirodu». Moskva: Izdatel'stvo «Indrik».]

Зеленин, Д. К., 1997: Великорусские сказки Пермской губернии. Санкт-Петербург: Издательство «Дмитрий Буланин». [Zelenin, D. K., 1997: Velikorusskie skazki Permskoj gubernii. Sankt-Peterburg: Izdatel'stvo «Dmitrij Bulanin».)

Зеленин, Д. К., 2002: Великорусские сказки Вятской губернии. Санкт-Петербург: Тропа Троянова. [Zelenin, D. K., 2002: Velikorusskie skazki Vjatskoj gubernii. Sankt-Peterburg: Tropa Trojanova.]

Златковић, Д., 2001: Срамотно и погано у пиротском говору. София: Диос. [Zlatkovič, D., 2001: Sramotno i pogano u pirotskom govoru. Sofija: Dios.]

Иванов, Вяч. Вс., Топоров, В. Н., 1974: Исследования в области славянских древностей: Лексические и фразеологические вопросы реконструкиии текстов. Москва: Издательство «Наука». [Ivanov, Vjač. Vs., Toporov, V. N., 1974: Issledovanija v oblasti slavjanskih drevnostej: Leksičeskie i frazeologičeskie voprosy rekonstrukcii tekstov. Moskva: Izdatel'stvo «Nauka».]

Иванов, Вяч. Всев., Топоров, В. Н., 1990: Мокошь. Мифологический словарь (ред. Е. М. Мелетинский). Москва: Советская энциклопедия. [Ivanov, Vjač. Vs., Toporov, V. N., 1990: Mokoš. Mifologičeskij slovar'(ed. E.M. Meletinskij). Moskva: Sovetskaja enciklopedija.]

Иващенко, К. Л., 2018: Календарные обряды Верхнего Дона. Липеикая область. Липецк: Липецкое областное краеведческое общество. [Ivaščenko, K. L., 2018: Kalendarnye obrjady Verhnego Dona. Lipeckaja oblast’. Lipeck: Lipeckoe oblastnoe kraevedčeskoe obščestvo.]

Кабакова, Г. И., Седакова, И. А., 1995: Герман. Славянские древности. Этнолингвистический словарь. T. $1(A-\Gamma)$. Москва: Международные отношения. [Kabakova, G. I., Sedakova, I. A., 1995: German. Slavjanskie drevnosti. Etnolingvističeskij slovar'. T. 1 (A-G), Moskva: Meždunarodnye otnošenija.]

Каблешкова, Р., 2003: Народната медицина. Етноложко изследване на Пловдивска област. София: Мултипринт. [Kableškova, R., 2003: Narodnata medicina. Etnoložko izsledvane na Plovdivska oblast. Sofija: Multiprint.]

Каспина, М. М., 2001: Сюжеты об Адаме и Еве в свете исторической поэтики: на материале древней и средневековой еврейской и славянской книжности. Кандидатская диссертация. Москва: РГГУ, филология. [Kaspina, М. М., 2001: Sjužety ob Adame i Eve v svete istoričeskoj poetiki: na materiale drevnej i srednevekovoj evrejskoj i slavjanskoj knižnosti. Kandidatskaja dissertacija. Moskva: RGGU, filologija.]

Песни, собранные П. В. Киреевским. Новая серия. Вып. II, часть 1, 1918. Москва: Печатня А. М. Снегиревой. [Pesni, sobrannye P.V. Kireevskim. Novaja serija. Vyp. II, čast'1, 1918. Moskva: Pečat'nja A. I. Snegirevoj.]

Краусс, Ф. С., 2009: Заветные истории южных славян. Т. 2. Москва: Научно-издательский центр «Ладомир». [Krauss, F. S., 2009: Zavetnye istorii južnyh slavjan. T. 2. Moskva: Naučno-izdatel'skij centr «Ladomir».]

Криптадї Федора Вовка: винайдення сороміцького. Етнографія сексуальности на межі ХІХ - XX століть, 2018. Київ: Критика. [Kryptadiji Fedora Vovka: vynajdennja soromic kogo. Etnografija seksual'nosty na meži XIX - XX stolit',2018. Kijev: Krytyka.] 
Кэмпбелл, Дж., 2018: Сила мифа. Москва: Издательский дом «Питер». [Kempbell, Dž., 2018: Sila mifa. Moskva: Izdatel'skij dom «Piter».]

Кюршунова, И. А., 2010: Словарь некалендарных личных имен, прозвищ и фамильных прозваний Северо-Западной Руси XV-XVII вв. Санкт-Петербург: Издательство «Дмитрий Буланин». [Kjuršunova, I. A., 2010: Slovar'nekalendarnyh ličnyh imen, prozvišč i famil'nyh prozvanij Severo-Zapadnoj Rusi XV - XVII vv. Sankt-Peterburg: Izdatel'stvo «Dmitrij Bulanin».]

Тысяча имен Богини Лалиты, 2018. Шри Лалита-сахасранама. Москва: Ridero. [Tysjača imen Bogini Lality, 2018. Šri Lalita-sahasranama. Moskva: Ridero.]

Латышские народные предания. Избранное, 1962. Рига: Издательство Академии Наук Латвийской ССР. [Latyšskie narodnye predanija. Izbrannoe, 1962. Riga: Izdatel'stvo Akademii Nauk Latvijskoj SSR.]

Левинтон, Г. А., Охотин, Н. Г., 1991 :«Что за дело им - хочу...»: О литературных и фольклорных источниках сказки А. С. Пушкина «Царь Никита и 40 его дочерей». Литературное обозрение 1991 № 11. 28-35 [Levinton, G. A., Ohotin, N. G., 1991: «Čto za delo im hoču...»O literaturnyh i fol'klornyh istočnikah skazki A. S. Puškina «Car' Nikita i 40 ego dočerej». Literaturnoe obozrenie 1991 № 11. 28-35.]

Левченко, М., 1928: Казки та оповідання з Поділля. В записах 1850-1860-х рp. Bun. I-II. Киів: 3 друкарні всеукраїнської Академії Наук [Levčenko, M., 1928: Kazky ta opovidannja z Podillja. V zapysah 1850-1860-h rr. Vyp. I-II. Kijev: Z drukarni vseukraijins'koj Akademiji Nauk.]

Логинов, К. К., 1996: Материалы по сексуальному поведению русских Заонежья. Секс и эротика в русской традиционной культуре (Сост. А. Л. Топорков). Москва: Научноиздательский центр «Ладомир». [Loginov, K. K., 1996: Materialy po sersual'nomu povedeniju russkih Zaonežja. Seks i erotika v russkoj tradicionnoj kul ture (ed.). Moskva: Naučno-izdatel'skij centr «Ladomir».]

Лойтер, С. М., 2001: Русский детский фольклор и детская мифология. Исследование и тексты. Петрозаводск: Карельский государственный педагогический университет. [Lojter, S. M., 2001: Russkij detskij fol'klor i detskaja mifologija. Issledovanie i teksty. Petrozavodsk: Karel'skij gosudarstvennyj pedegogičeskij universitet.]

Легенди та перекази (Українська народна творчість.), 1985. Київ: Наукова думка. [Legendy ta perekazy (Ukrajins'ka narodna tvorčist'.), 1985. Kiev: Naukova dumka.]

Мелетинский, Е. М., 1995: Поэтика мифа. Москва: Издательская фирма «Восточная литература» РАН. [Meletinskij, E. M., 1995: Poetika mifa. Moskva: Izdatel'skaja firma «Vostočnaja literatura».]

Мелетинский, Е. М., 1998: Миф и историческая поэтика фольклора. Избранные статьи. Воспоминания. Москва: Российский государственный гуманитарный университет. [Meletinskij, E. M., 1998: Mif i istoričeskaja poetika fol'klora. Izbrannye stat î. Vospominanija. Moskva: Rossijskij gosudarstvennyj gumanitrnyj universitet.]

Мијатовић, С. М., 1909: Народна медицина срба сељака у Левчу и Темнићу. Српски етнографски зборник (уредио Тих. Р. Ђорђевић), књ. ХІІІ. Београд: Штампано у Државној штампарији Краљевине Србије. [Mijatovič, S. M., 1909: Narodna medicina srba seljaka u Levču i Temniću. Srpski etnografski zbornik (ed.Tih. R. Džordževič), knj. XIII. Beograd: Ščtampano u Državnoj ščampariji Kral'evine Srbije.]

Мильов, С, 2002: Скришен фолклор. София: Огледалото. [Mil'ov, S., 2002: Skrišen folkor. Sofija: Ogledaloto.] 
Миненок, Е. В., Капица, Ф. С., 1995: Загадки из фольклорного архива МГУ. Русский эротический фольклор (Сост. А. Л. Топорков). Москва: Научно-издательский центр «Ладомир». [Minenok, E. V., Kapica, F. S., 1995: Zagadki iz fol'klornogo arhiva MGU. Russkij erotićeskij fol'klor (ed. A. L. Toporkov). Moskva: Naučno-izdatel'skij centr «Ladomir».]

Мороз, Е., 2011: Веселая Эрата. Секс и любовь в мире русского Средневековья. Москва: Новое литературное обозрение. [Moroz, Е., 2011: Veselaja Erata. Seks i ljubov'v mire russkogo Srednevekovja. Moskva: Novoe literaturnoe obozrenie.]

Морозов, И. А., Слепцова, И. С., 1996: Свидание с предком (Пережиточные формы ритуального брака в святочных забавах ряженых). Секс и эротика в русской традиционной культуре (Сост. А. Л. Топорков). Москва: Научно-издательский центр «Ладомир». [Morozov, I. A., Slepcova, I. S., 1996: Svidanie s predkom (Perežitočnye formy ritual'nogo braka v svjatočnyh zabavah rjaženyh). Seks i erotica v russkoj tradicionnoj kul'ture (ed. A. L. Toporkov). Moskva: Naučno-izdatel'skij centr «Ladomir».]

Морозова, Н., Новиков, Ю., 2007: Чудное Причудье. Фольклор староверов Эстонии. Тарту: Издательство HUMA. [Morozova, N., Novikov. Ju., 2007: Čudnoe Pričud'e. Fol'klor staroverov Estonii. Tartu: Izdatel'stvo HUMA.]

В некотором иарстве. Сказки родного края, 1994. (Составитель В. Н. Морохин). Нижний Новгород: Издательство «Фора». [V nekotorom carstve. Skazki rodnogo kraja, 1994. (Sostavitel' V. N. Morohin). Nižnij Novgorod: Izdatel'stvo «Fora».]

Мутина, А. С., 2005: «Катится изюминка...» Современный русский детский фольклор Удмуртии. Ижевск: Удмуртский институт истории, языка и литературы УрО РАН. [Mutina, A. S., 2005: «Katitsja izjuminka ...» Sovremennyj russkij detskij fol'klor Udmurtii, Iževsk: Udmurtskij institut istorii, jazyka i literatury UrO RAN.]

Мифологические рассказы и поверья Нижегородского Поволжья, 2007. Санкт-Петербург: Тропа Троянова. [Mifologičeskie rasskazy i poverja Nižegorodskogo Povolžja, 2007. Sankt-Peterburg: Tropa Trojanova.]

Митология на човешкото тяло. Антропологичен речник, 2008. София: Академично издателство «Проф. Марин Дринов». [Mitologija na čoveškoto tjalo. Antropologičen rečnik, 2008. Sofija: Akademično izdatelstvo «Prof. Marin Drinov».]

Назаров, В. Д., 1999: «Срамословие» в топонимике России XV-XVI вв. «A се грехи злье, смертные ...». Любовь, эротика и сексуальная этика в доиндустриальной России (Xпервая половина XIX в.). Москва: Научно-издательский центр «Ладомир». [Nazarov, V. D., 1999: «Sramoslovie» v toponimike Rossii XV-XVI vv. «A se grehi zlye, smertnye...». Ljubov', erotica i seksual'naja etika $v$ doindustrial'noj Rossii ( $X$ - pervaja polovina XIX v.). Moskva: Naučno-izdatel'skij centr «Ladomir».]

Никитина, Н. А., 1994: К вопросу о русских колдунах. Русское колдовство, ведовство, знахарство. Санкт-Петербург: Издательство «Литера». [Nikitina, N. А., 1994: K voprosu o russkih koldunah. Russkoe koldovstvo, vedovstvo, znaharstvo. Sankt-Peterburg: Izdatel'stvo «Litera».]

Никифоров, А. И., 1961: Севернорусские сказки. Москва, Ленинград: Издательство Академии Наук CCCP. [Nikiforov, A. I., 1961: Severnorusskie skazki. Moskva, Leningrad: Izdatel'stvo Akademii Nauk SSSR.]

Новгородские былины, 1978 (ред. Ю. И. Смирнов, В. Г. Смолицкий). Ленинград: Издательство «Наука». [Novgorodskie byliny, 1978. (ed. Ju. I. Smirnov, V. G. Smolickij, Leningrad: Izdatel'stvo «Nauka»] 
«Народная библия»: Восточнославянские этиологические легенды, 2004. Москва: Издательство «Индрик». [«Narodnaja biblija»: Vostočnoslavjanskie etiologičeskie legendy, 2004. Moskva: Izdatel'stvo «Indrik».]

Овчаров, Д., 1993: Сексуалното и сакралното в културен аспект. Фолклорен еротикон. $T$. I. (ред. Ф. Бадаланова). София: Импресарско-издателска къща «РОД». [Ovčarov, D., 1993: Seksualnoto i sakralnototo v kulturen aspect. Folkloren erotikon. T. I. (ed. F. Badalanova). Sofija: Impresarsko-izdatelska kešča «ROD».]

Озорные частушки («с картинками»), 1995. Санкт-Петербург: Издательство «Атос» [Ozornye častuški («s kartinkami»), 1995. Sankt-Peterburg: Izdatel'stvo «Atos»].

Заветные сказки из собрания Н. Е. Ончукова, 1996. Москва: Научно-издательский центр «Ладомир». [Zavetnye skazki iz sobranija N. E. Ončukova, 1996. Moskva: Naučno-izdatel'skij centr «Ladomir».]

Павлова, М. Р., 1985: Среда и пятница в связи с прядением. Этногенез, ранняя этническая история и культура славян. Москва: Издательство «Наука». [Pavlova, M. R.: Sreda i pjatnica v svjazi s prjzdeniem. Etnogenez, rannjaja etničeskaja istorija i kul'tura slavjan, 1985. Moskva: Izdatel'stvo «Nauka».]

Петкевич, Г., 1911 Материалы по народной медицине литовцев. Живая старина. Вып. 2, Санкт-Петербург. 168-218. [Petkevič, G., 1911: Materialy po narodnoj medicine litovcev. Živaja starina. Vyp. 2. Sankt-Peterburg. 168-218.]

Плосс, Г., 1995: Женщина в естествоведении и народоведении (В 3 т. Т. 1). Сыктывкар, Киров: Вятка. [Ploss, G., 1995: Ženščina v estestvovedenii i narodovedenii (v 3 t. T. 1). Syktyvkar, Kirov: Vjatka].

Плотникова, А. А., 1995: Воск. Славянские древности. Этнолингвистический словарь. T. 1 $(A-\Gamma)$. Москва: Международные отношения. [Plotnikova, A. A., 1995: Vosk. Slavjanskie drevnosti. Etnolingvističeskij slovar'. T. 1 (A-G). Moskva: Meždunarodnye otnošenija.

Плуцер-Сарно, А., 2001: Большой словарь русского мата. T. 1. Санкт-Петербург: Лимбус Преcc. [Plucer-Sarno, A., 2001: Bol'soj slovar' russkogo mata. T. 1. Sankt-Peterburg: Limbus Press.]

Плуцер-Сарно, А., 2005: Материалы к словарю русского мата. Т. 2. Санкт-Петербург, Москва: Лимбус Пресс. [Plucer-Sarno, А., 2005: Materialy k slovarju russkogo mata. T. 2. Sankt-Peterburg, Moskva: Limbus Press.)

И смех и грех. Эротика в пермском фольклоре. Сказки, бывальщины, заговоры, загадки, песни, частушки (Соб. И. Подюков, С. Хоробрых), 2001. Пермь: ПРИЛИТ. [I smeh i greh. Erotika v permskom fol'klore. Skazki, byval'ščiny, zagovory, zagadki, pesni, častuški. (Sob. I. Podjukov, S. Horobryh), 2001. Perm': PRILIT.]

Полное Собрание Законов Российской Империи. Собрание первое. С 1649 по 12 декабря 1825 года. T. 18: 1767-1769, 1830. Санкт-Петербург: Печатано в Типографии II Отделения Собственной Его Императорского Величества Канцелярии. [Polnoe Sobranie Zakonov Rossijskoj Imperii. Sobranie pervoe. S 1649 gj 12 dekabrja 1825 goda. T. 18: 1767-1769, 1830. Sankt-Peterburg: Pečatano v Tipografii II Otdelenija Sobstvennoj E. I. Veličestva Kanceljarii.]

Померанцева, Э. В., 1975: Ярилки. Советская этнография, № 3. 127-130. Москва: Издательство «Наука». [Pomeranceva, E. V., 1975: Jarilki. Sovetskaja etnografija, № 3, 127-130. Moskva: Izdatel'stvo «Nauka».]

Потебня, А. А., 1865: О мифическом значении некоторых обрядов и поверий. Москва: В Университетской типографии. [Potebnja, А. A., 1865: O mifičeskom značenii nekotoryh obrjadov i poverij, Moskva: V Universitetskoj tipografii.] 
Пропп, В. Я., 1998: Поэтика фольклора. Москва: Лабиринт. [Propp, V. Ja., 1998: Poetika fol'klora. Moskva: Labirint.]

Пушкин, А. С., 1947: Полное собрание сочинений. В 16 m. T. 2, кн. 1. Стихотворения, 1817-1825. Лицейские стихотворения в позднейших редакциях. Москва, Ленинград: Издательство Академии Наук СССР. [Puškin, A. S., 1947: Polnoe sobranie sočinenij. V 16 t. T. 2, kn. 1. Stihotvorenija. 1817-1825. Licejskie stihotvorenija v pozdnejših redakcijah. Moskva, Leningrad: Izdatel'stvo Akademii Nauk SSSR.]

Радин, П., 1999 Трикстер. Исследование мифов североамериканских индейщев с комментариями К. Г. Юнга и К. К. Кереньи. Санкт-Петербург: Евразия. [Radin, P., 1999 Trikster. Issledovanie mifov severoamerikanskih indejcev s kommentarijami K. G. Junga i K. K. Keren'i. Sankt-Peterburg: Evrazija.]

Реутин, М. Ю., 1996. Народная культура Германии: Позднее средневековье и Возрождение. Москва: Российский государственный гуманитарный университет. [Reutin, M. Ju., 1996: Narodnaja kul'tura Germanii: Pozdnee srednevekov'e i Vozroždenie. Moskva: Rossijskij gosudarstvennyj gumanitrnyj universitet.]

Речник српскохрватског књижевног и народног језика. Кюь. V, 1968. Београд: Институт за српскохрватски језик. [Rečnik srpskohrvtskog književnog i narodnog jezika. Knj. V, 1968. Beograd: Institut za srpskohrvatski jezik.]

Романов, Е. Р., 1885: Белорусский сборник. Bып. 1-2. Песни, пословицы, загадки. Киев: Типография С. В. Кульженко. [Romanov, Е. R., 1885: Belorusskij sbornik. Vyp. 1-2. Pesni, poslovicy, zagadki. Kiev: Tipografija S. V. Kul'ženko.]

Романов, Е. Р., 1891: Белорусский сборник. Вып. 5. Заговоры, апокрифы и духовные стихи. Витебск: Типо-литография Г. Г. Малкина. [Romanov, E. R., 1891: Belorusskij sbornik. Vyp. 5. Zagovory, apokrify i duhovnye stihi. Vitebsk: Tipo-lotografija G. G. Malkina.]

Рут, М. Э., 1987: Русская народная астронимия. Свердловск: Уральский государственный университет. [Rut, M. Е., 1987: Russkaja narodnaja astronimija. Sverdlovsk: Ural'skij gosudarstvennyj universitet.]

Рут, М. Э., 2003: Северный астронимический тип в севернорусской интерпретации. Рябининские чтения - 2003. Материаль IV научной конференщии по изучению народной культуры Русского Севера. Петрозаводск: Музей-заповедник «Кижи». [Rut, M. Е., 2003: Severnyj astronimičeskij tip v severnorusskoj interpretacii. Rjabininskie čtenija-2003. Materialy IV naučnoj konferencii po izučeniju narodnoj kul'tury Russkogo Severa. Petrozavodsk: Muzej-zapovednik «Kiži».]

Рут, М. Э., 2010: Словарь астронимов. Звездное небо по-русски. Москва: АСТ-ПРЕСС. [Rut, M. E., 2010: Slovar'astronimov. Zvezdnoe nebo po-russki. Moskva: AST-PRESS.]

Русские волшебные сказки Сибири, 1981. Новосибирск: Издательство «Наука». Сибирское отделение. [Russkie volšebnye skazki Sibiri, 1981. Novosibirsk: Izdatel'stvo «Nauka». Sibirskoe otdelenie.]

Русский демонологический словарь (Составитель Т. А. Новичкова), 1995. Санкт-Петербург: Петербургский писатель. [Russkij demonologičeskij slovar'(ed. T. А. Novičkova). Sankt-Peterburg: Peterburgskij pisatel'.]

Русские сказки и песни в Сибири. Записки Красноярского подотдела Восточно-Сибирского отдела Императорского Русского Географического Общества по этнографии, 2000. Санкт-Петербург: Тропа Троянова. [Russkie skazki i pesni v Sibiri. Zapiski Krasnojarskogo podotdela Vostočno-Sibirskogo otdela Imperatorskogo Russkogo Geografičeskogo Obščestva po etnografii, 2000. Sankt-Peterburg: Tropa Trojanova.] 
Русские сказки Урала (Из фондов Свердловского областного Дома фольклора), 1997. Екатеринбург: Сфера. [Russkie skazki Urala (Iz fondov Sverdlovskogo oblastnogo Doma fol'klora), 1997. Ekaterinburg: Sfera.]

«Ты не жми меня к березе...» Русские частушки без цензуры, 1993. Москва: ЛИНФ. [«Ту пе žmi menja k breeze...» Russkie častuški bez cenzury, 1993. Moskva: LINF.]

Русский эротический фольклор. Песни, обряды и обрядовый фольклор, народный театр, заговоры, загадки, частушки, 1995. Москва: Научно-издательский центр «Ладомир». [Russkij erotićeskij fol'klor. Pesni, obrjady i obrjadovyj fol'klor, narodnyj teatr, zagovory, zagadki, častuški, 1995. Moskva: Naučno-izdatel'skij centr «Ladomir».]

Рыбаков, Б. А., 1987: Язычество Древней Руси. Москва: Издательство «Наука». [Rybakov, B. A., 1987: Jazyčestvo Drevnej Rusi. Moskva: Izdatel'stvo «Nauka».]

Рыжакова, С. И., 2002: Язык орнамента в латышской народной культуре. Москва: Издательство «Индрик». [Ryžakova, S. I., 2002: Jazyk ornamenta v latyšskoj narodnoj kul'ture, Moskva: Izdatel'stvo «Indrik».]

Городская и деревенская повивальная бабка. Пер. с французского Д. Самойлович, 1780. Москва: В Университетской типографии у Н. Новикова,. [Gorodskaja i derevenskaja povival'naja babka. Per. s francuzskogo D. Samojlovič, 1780. Moskva: V universitetskoj tipografii u N. Novikova.]

Сказания русского народа, собранные И. П. Сахаровым. Т. 2, кн. 7, 1849. Санкт-Петербург: В типографии Сахарова. [Skazanija russkogo naroda, sobrannye I. P.Saharovym. T. 2, $k n .7,1849$. Sankt-Peterburg: V tipografii Saharova.]

Сказки Заонежья (Составитель Н. Ф. Онегина), 1985. Петрозаводск: Карелия. [Skazki Zaonežja (Sostavitel' N. F. Onegina), 1985. Petrozavodsk: Karelija.]

Великорусские сказки архива Русского Географического Общества. Сборник А. М. Смирнова. Книга 2, 2003. Санкт-Петербург: Тропа Троянова. [Velikorusskie skazki arhiva Russkogo Geografičeskogo Obščestva. Sbornik A. M. Smirnova. Kniga 2, 2003. Sankt-Peterburg: Tropa Trojanova.]

Сказки и песни Белозерского края. Сборник Б. и Ю. Соколовых: В 2 кн. Книга 1, 1999. Санкт-Петербург: Тропа Троянова. [Skazki i pesni Belozerskogo kraja. Sbornik B. i Ju. Sokolovyh: V 2 knigah. Kniga 1, 1999. Sankt-Peterburg: Tropa Trojanova.]

Словарь русских народных говоров. Вып. 9 (Ерепеня - Заглазеться), 1972. Ленинград: Издательство «Наука». Ленинградское отделение. [Slovar' russkih narodnyh govorov. Vyp. 9 (Erepenja - Zaglazet'sja), 1972. Leningrad: Izdatel'stvo «Nauka». Leningradskoe otdelenie]

Словарь современного русского народного говора (д. Деулино Рязанского района Рязанской области), 1969. Москва: Издательство «Наука». [Slovar'sovremennogo russkogo narodnogo govora (d. Deulino Rjazanskogo rajona Rjazanskoj oblasti), 1969. Moskva: Izdatel'stvo «Nauka».]

Пискунова С. В. и др. (ред.), 2001: Словарь тамбовских говоров (духовная и материальная культура). Тамбов: Издательство Тамбовского государственного университета имени Г. Р. Державина. [Piskunova, S. V. i dr. (eds.), 2001: Slovar'tambovskih govorov (duhovnaja i material'naja kul'tura). Tambov: Izdatel'stvo Tambovskogo gosudarstvennogo universiteta imeni G. R. Deržavina.]

Гуйванюк Н. В. (заг. ред.), 2005: Словник буковинських говірок. Чернівці: Рута. [Gujvanjuk N. V. (ed.), 2005: Slovnyk bukovyns kyh govirok. Černivci: Ruta.]

Слоўнік гаворак иэнтральных раёнаў Беларусі. У 2 m. T. 1 (А-П), 1990. Мінск: Універсітэцкае. [Slovnik gavorak central'nyh rajonav Belarusi. U 2 t. T. 1 (A-P), 1990. Minsk: Universiteckae.] 
Словник української мови. В 11 m. T. 2 (Г-Ж), 1971. Кіїв: Наукова думка. [Slovnyk ukrajns'skoj movy. V 11 t. T. $2(G-\check{Z}), 1971$. Kijev: Naukova dumka.]

Словник української мови. В 11 m. T. 4 (I-M), 1973. Кіїв: Наукова думка. [Slovnyk ukrajns'skoj movy. V 11 t. T. 2 (I-M), 1973. Kijev: Naukova dumka.]

Снегирев, И., 1839: Русские простонародные праздники и суеверные обряды. Ч. 4. Москва: В Университетской Типографии. [Snegirev, I. 1839: Russkie prostonarodnye prazdniki

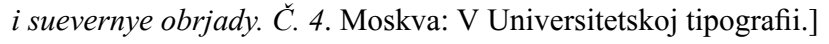

Судник, Т. М., Цивьян, Т. В., 1978: К реконструкции сюжета основного мифа в балто-славянской перспективе (фрагмент «Жена и дети Громовержца»). Этнолингвистические балтославянские контакты в настоящем и прошлом. Москва: Издательство «Наука». [Sudnik, T. N., Civjan, T. V., 1978: K rekonstrukcii sjužeta osnovnogo mifa v balto-slavjanskoj perspective (fragment «Žena i deti Gromoveržca»). Etnolingvističeskie balto-slavjanskie kontakty v nastojaščem i prošlom, Moskva: Izdatel'stvo «Nauka».]

Терещенко, А., 1848: Быт русского народа. Ч. 5. Санкт-Петербург: В типографии военноучебных заведений. [Tereščenko, A., 1848: Byt russkogo naroda. Č. 5. Sankt-Peterburg: V tipografii voenno-učebnyh zavedenij.]

Токарев, С. А., 1980: Обряды и мифы. Мифы народов мира: Энщиклопедия. T. 2. Москва: Издательство «Советская энциклопедия». [Tokarev, S. A., 1980: Obrjady i mify. Mify narodov mira: Enciklopedija. T. 2, Moskva: Izdatel'stvo «Sovetskaja enciklopedija».]

Толстой, Н. И., 1995: Гениталии. Славянские древности. Этнолингвистический словарь. Т. 1 $(A-\Gamma)$. Москва: Международные отношения. [Tolstoj, N. I. 1995: Genitalii. Slavjanskie drevnosti. Etnolingvističeskij slovar'. T. 1 (A-G). Moskva: Meždunarodnye otnošenija.]

Толстая, С. М., 2009: Пятница. Славянские древности. Этнолингвистический словарь. T. 4 (Переправа-Cито). Москва: Международные отношения. [Tolstaja, S. M., 2009: Pjatnica. Slavjanskie drevnosti. Etnolingvističeskij slovar'. T. 4 (Pereprava-Sito) Moskva: Meždunarodnye otnošenija.]

Топорков, А. Л., 1992: Перепекание детей в ритуалах и сказках восточных славян. Фольклор и этнографическая действительность. Санкт-Петербург: Наука. С-Петербургское отделение. [Toporkov, A. L., 1992: Perepekanie detej v ritualah i skazkah vostočnyh slavjan. Fol 'klor i etnografičeskaja dejstvitel'nost'. Sankt-Peterburg: Izdatel'stvo «Nauka». S-Peterburgskoe otdelenie.]

Традиционная культура Ульяновского Присурья. Этнодиалектный словарь. В 2 m. T. 2, 2012. Москва: Издательство «Индрик». [Tradicionnaja kul'tura Ul'janovskogo Prisurja. Etnidialektnyj slovar'. V 2 t. T. 2, 2012. Moskva: Izdatel'stvo «Indrik».]

Традыиыйная мастаикая культура беларусай. У 6 тамах. Т. 4. Брэсикае Палессе. Кн. 2, 2009; T. 6. Гомельскае Палессе і Падняпроўе. Кн. 2, 2013. Мінск: Вышэйшая школа. [Tradycyjnaja mastackaja kul'tura belarusav. U 6 tamah. T. 4. Bresckae Palesse. Kn. 2, 2009; T. 6. Gomel'skae Palesse i Padnjaprove. Kn. 2, 2013. Minsk: Vyšejšaja škola.]

Трыкова, О. Ю., 2003: Детская литература и фольклор: аспекты взаимодействия, Ярославль: LAP LAMBERT Academic Publishing. [Trykova, O. Ju., 2003: Detskaja literatura i fol'klor: aspekty vzaimodejstvija. Jaroslavl': LAP LAMBERT Academic Publishing].

Тупиков, Н. М., 1903: Словарь древнерусских личных имен. Санкт-Петербург: Типография И. Н. Скороходова. [Tupikov, N. М., 1903: Slovar’ drevnerusskih ličnyh imen. Sankt-Peterburg: Tipografija I. N. Skorohodova.]

У истоков мира: Русские этиологические сказки и легенды (сост. и коммент. О. В. Беловой, Г. И. Кабаковой), 2014. Москва: Форум; Неолит. [U istokov mira: Russkie etiologičeskie skazki i legendy (eds. O. V. Belovoj, G. I. Kabakovoj), 2014. Moskva: Forum, Neolit.] 
Успенский, Б. А., 1982: Филологические разыскания в области славянских древностей. Москва: Издательство Московского университета. [Uspenskij, В. А., 1982 Filologičeskie razyskanija v oblasti slavjanskih drevnostej. Moskva: Izdatel'stvo Mokovskogo universiteta.]

Успенский Б. А., 1994: «Заветные сказки» А. Н. Афанасьева. Успенский Б. А. Избранные труды. T. 2, Москва: Гнозис. [Uspenskij, B.A. 1994: «Zavetnyje skazki» A.N. Afanas'eva in: Uspenskij, B.A. Izbrannye trudy. T. 2, Moskva: Gnozis.]

Україньскі сороміцькі пісні, 2003. Харьків: Фоліо [Ukrajn’ski soromic 'ki pisni, 2003. Har'kiv: Folio.]

Филиповић, М. С., 1933: Славонски вотиви од воска. Гласник Етнографског Музеја у Београду. Къ. 8. Београд: Државна штампарија Краљевине Југославије. [Filipovič, M. S., 1933: Slavonski votive od voska. Glasnik Etnografskog Muzeja u Beogradu. Knj. 8. Beograd: Državna ščamparija Kral'evine Jugoslavije.]

Фолклорен еротикон. Т. I. (сост. Ф. Бадаланова), 1993. София: Импресарско-издателска къща «РОД». [Folkloren erotikon. T. I. (sost. F. Badalanova), 1993. Sofija: Impresarsko-izdatelska kešča «ROD».]

Фольклор старообрядиев Литвы. В 3 m. Т. 1. Сказки. Пословищьл. Загадки, 2007. Вильнюс: Vilniaus pedagoginis universitetas. [Fol'klor staroobrjadcev Litvy. V 3 t. T. 1. Skazki. Poslovicy. Zagadki 2007. Vil'njus: Vilniaus pedagoginis universitetas.]

Холл, Д., 1996: Словарь сюжетов и символов в искусстве. Москва: Крон-пресс. [Holl, D., 1996: Slovar'sjužetov i simvolov v iskusstve. Moskva: Kron-press.]

Христофорова, О., 2013: Икота. Мифологический персонаж в локальной традиции. Москва: Российский государственный гуманитарный университет. [Hristoforova, O., 2013: Ikota. Mifologičeskij personaž v lokal'noj tradicii. Moskva: Rossijskij gosudarstvennyj gumanitrnyj universitet.]

Худяков, И. А., 2001: Великорусские сказки. Великорусские загадки. Санкт-Петербург: Тропа Троянова. [Hudjakov, I. A., 2001: Velikorusskie skazki. Velikorusskie zagadki. Sankt-Peterburg: Tropa Trojanova.]

Хукка, В. С., 1992: Жаргон и аббревиатура татуировок преступного мира: словарь-справочник. Нижний Новгород: Нижполиграф. [Hukka, V. S., 1992: Žargon i abbreviatura tatuirovok prestupnogo mira: slovar'-spravočnik. Nižnij Novgorod: Nižpoligraf.]

Цыхун, А., 2014: Скарбы народнай мовы. 3 лексічнай спадчыны насельнікаў Гарадзенскага раёну. Гародня: Гарадзенская бібліятэка. [Cyhun, A., 2014: Skarby narodnaj movy. Z leksičnaj spadčyny nasel'mikav Garadzenskaga rajonu. Garodhja: Garadzenskaja biblijateka.]

Чубинский, П. П., 1878: Труды этнографическо-статистической экспедичии в ЗападноРусский край. T. 2. Малорусские сказки. Петербург: Типография и хромолитография А. Траншеля. [Čjubinskij, P. P., 1878: Trudy etnografičesko-statističeskoj ekspedicii v Zapadno-Russkij kraj. T. 2. Malorusskie skazki. Peterburg: Tipigrafija i hromolitografija A. Tranščelja.]

Сказки Шадринского края (собиратели и составители: В. Бекетова, В. Тимофеев), 1995. Шадринск: Издание Шадринского пединститута. [Skazki Šadrinskogo kraja (edit: V. Beketova, V. Timofeev), 1995. Šadrinsk: Izdanie Ščadrinskogo pedinstituta.]

Шатэрнік, М., 1929: Краёвы слоўнік Чэрвэншчыны. Менск: Выданьне Беларускае Акадэміі Навук. [Šaternik, M., 1929: Krajovy slovnik Červenščyny. Mensk: Vydan'ne Belaruskae Akademii Navuk.]

Шухевич, В., 1908: Гуиульщинна. Ч. 5. Львів: 3 «Загальної друкарнї». [Šuhevič, V., 1908: Gucul'ščina. Č. 5, L'viv: Z «Zagal'noj drukarni».] 
Устьянские сказки, бывальщины и легенды (Предисловие и публикация В. И. Щипина), 2007. Живая старина, № 1, С. 42-46. Москва: Государственный республиканский центр русского фольклора. [Ust'janskie skazki, byval'ščiny i legendy (Predislovie i publikacija V.I. Ščipina), 2007. Živaja starina, № 1, S. 42-46. Moskva: Gosudarstvennyj respublikanskij centr russkogo fol'klora.]

Элиаде, М., 2002: История веры и религиозных идей. T. III. Москва: Критерион. [Eliade, М., 2002: Istorija very i riligioznyh idej. T. III. Moskva: Kriterion.]

Народные сказки, собранные сельскими учителями. Сборник А. А. Эрленвейна, 2005. СанктПетербург: Тропа Троянова. [Narodnye skazki, sobrannye sel'skimi učiteljami. Sbornik A.A. Erlenvejna, 2005. Sankt-Peterburg: Tropa Trojanova.]

Этимологический словарь славянских языков. Праславянский лексический фонд. Вып. 19, 1992. Москва: Издательство «Наука». [Etimologičeskij slovar'slavjanskih jazykov. Praslavjanskij leksičeskij fond. Vyp. 19, 1992. Moskva: Izdatel'stvo «Nauka».]

Becker, R., 1990: Die weibliche initiation im ostslawischen Zaubermärchen: ein Beitrag zur Funktion und Symbolik des weiblichen Aspektes im Märchen unter besonderer Berücksichtigung der Figur der Baba-Jaga. Berlin: Wiesbaden by Harrassowitz.

Biegileisen, H., 1929: Lecznictwo ludu polskiego. Kraków: Polska Akademja Umiejętności.

Burkhart, D., 2000: Erotska tradicija u Rusiji: Puškin i njegova priča u stihovima Car Nikita i njegovih četrdeset kćeri. Erotsko u folklore slovena (ed. D. Ajdačić). Beograd: Stubovi kulture.

Federowski, M., 1897: Lud białoruski na Rusi Litewskiej. T. I. Krakow: Nakładem Akademji Umiejętności.

Folklore de Ukraine: Usages, contes et legendes, chansons, proverbs etjurons, 1898. Kryptadia. Vol. 5. Paris: Imprimirie G. Uschmann a Weimar.

Gimbutas, M., 1989: The Language of the Goddess. London: Harper \& Row.

Hnatjuk, V., 1909: Das Geschliechtleben des ukrainischen bauernvolkes folkloristische erhebungen aus der russischen Ukraina. Aufzeichnungen von Pavlo Tarasevkyj, einleitung und parallelennachweise tos Volodymir Hnatjuk (Biewerke zum stadium der Anthropophyteia. Band III). Liepzig: Deutsche Verlagaktiengesellschaft.

Kajmaković R., 1974: Semberija. Etnološka monografija. Sarajevo: Posebni otisak iz glasnika zemaljskog muzeja Bosni i Gercegovine u Sarajevu.

Kolberg, O., 1881: Dzieła wszistkie. T. XIV. Poznańskie. Cz. VI. Kraków: W drukarni Uniwersytetu Jagiellońskiego.

Krekovičova, E., 2000: Erotski motivi u slovačkim narodnim pesmama. Erotsko u folklore slovena (ed. D. Ajdačić). Beograd: Stubovi kulture.

Kukuljević, I. Vile, 1851: Arkiv za pověstnicu jugoslavensku. Knj. I. Zagreb: Izdano troškom Družtva za jugoslavensku povestnicu i starine.

Lovretić, J., 1902: Otok. Narodni život i običaji. Zbornik za narodni život i običaje južnih slavena, Kn. VII, Sv. 1. Zagreb: Knižara Jugoslavenske Akademije.

Rulikowski, E., 1853: Opis powiatu Wasylkowskiego pod względem historycznym, obyczajowym i statystycznym. Warszawa: W drukarni S. Orgelbranda.

Słownik gwar polskich. T. VI (U-Ż). Ulożił J. Karłowicz, 1911. Kraków: Drukarnia Uniwersytetu Jagiellońskiego.

Sychta, B., 1973: Stownik gwar kaszubskich na tle kultury ludowej. T. VI (U-Ž). Wrocław, Warszawa, Kraków, Gdańsk: Wydawnictwo Polskiej Akademii Nauk.

Varłyha, A., 1970: Krajovy stoŭnik Łahojščyny. New York: Vydańnie ZARANKA. 


\section{AETIOLOGICAL NOTES: "THE STORY OF IVAN"}

\section{Bogumil Gasanov \\ $\infty \infty$}

Among the Ukrainian folk erotic texts published by Fedor Vovk in vol. 5 of his book КРYПТ'A $\triangle$ IA, (Paris, 1898), one tale differs dramatically because of its plot: Ivan, a father of seven daughters without vaginas, goes to a woman called Anastasia, buys from her the missing parts, cuts some space in their bodies with an axe, and inserts the vaginas. Anastasia also gives him an extra vagina, which threatens to stay on Ivan's nose. Ivan cuts it into pieces with the axe and makes clitorises for his daughters.

The plot similarities of this text, titled "The Story about Ivan", with Pushkin's "Tsar Nikita and his forty daughters" makes us consider their possible connection. The retelling of Pushkin's work seems impossible due to the mismatches of many important details. It only remains to assume a common source for both texts: Pushkin heard a similar version of "The Story" and processed it creatively.

Analysis of the elements in "The Story about Ivan" supports the conclusion that this text has a folk character. Almost all of its parts have analogies in East Slavonic folklore; typical motifs are used.

In the Slavonic tradition, there are etiological legends close to "The Story about Ivan". They concern the appearance of genitalia in the first humans (or only females). The figures of Ivan and Anastasia from the analysed text might go back to the images of the pagan deities (Rod and Mokosh?), personages of the myth about creating genitals. The text itself is probably an echo of an etiological legend, preserved in the form of an obscene story that lost its "explanatory part".

Bogumil Gasanov, independent researcher, Russia, Rjazan, 390026, st. Leninskogo komsomola, 101-128, bogumil13@mail.ru 